\title{
Educational and vocational guidance and information services for the youth in public libraries
}

\author{
J A Fourie' \\ Department of Information Science, Unisa \\ fourija@unisa.ac.za
}

\begin{abstract}
Received: $7^{\text {th }}$ December 2006
Accepted: I $^{\text {st }}$ March 2007
\end{abstract}

\begin{abstract}
The results of an investigation into the public library's role in the provision of educational and vocational guidance and information to the youth and its links to the school and other career guidance service providers in South Africa are reported. The empirical study focused on public library services to the youth in general and to high school learners in particular.

The results showed that public libraries continue to provide separate user services to children but that separate provision is only made for teenagers and young adults in the case of large public libraries. Career-related requests are frequently received from high school learners but inadequate resources affect the development of specialised educational and vocational guidance and information services (EVGIS) for them. Lack of cooperation between public libraries, schools and other career guidance service providers hinders the development of support networks for learners.

It is recommended that existing general user services to the youth could be extended to introduce specialised EVGIS for high school learners. Recommendations are made in respect of collections, facilities, staff and funding.
\end{abstract}

Keywords: Public library services; educational guidance; career guidance; youth information services; high school learners.

\section{Introduction}

Young people in South Africa face a number of serious problems in terms of the educational system and employment. There are high rates of unemployment among the economically active youth. In addition, wrong subject choices at school and poor examination results are the result of a lack of quality school guidance (Kruger 1995:10-11,43; Jennings et al. 1997:40; Van Zyl Slabbert et al. 1994:59,70, 109).

The educational support services of the Department of Education are responsible for school guidance programmes in South Africa but these programmes are hampered by financial constraints and low teacher-learner ratios (Molefe 1994:263; Moolla 1996:3-4). The Department envisages that individual guidance will have to be addressed by professional counsellors and other guidance practitioners in the local community outside the school who it is hoped will form networks of educational support for learners (Quality education for all ... 2003:64-65, 104-107). However, communitybased organisations tend to focus primarily on out-of-school and unemployed youth rather than high school learners (Potgieter [1999]:33).

The provision of information is fundamental to a comprehensive school guidance programme. School counsellors have to assist learners in applying information in career decision-making. However, few schools have full-time counsellors with specialised guidance qualifications (Van Niekerk 2002:3). The school library is a vital resource centre for career information. Teacher-librarians view cooperation with school counsellors as essential (Human 1992:96; White \& Wilson 1997:2-6). However, most schools in South Africa do not have properly functioning libraries and few have full-time teacher-librarians (Lor 1998:7-8; Naidoo 1997:7). The public library could be an important source of support for the school guidance programme. However, the issue is whether the public library has the capacity to offer a complete career guidance and information service to the youth and whether it cooperates with the school and other career guidance service providers.

The study on which this article is based addressed the question of the role of the public and community library in meeting the educational and vocational guidance and information needs of the youth, and its links to other service providers.

\section{Definitions}

School guidance comprises four areas, namely educational, vocational, personal and social guidance. Educational guidance in schools involves help with study difficulties or the choice of subjects most suitable for the school learner's abilities and future career. Educational information includes knowledge of educational and vocational institutions at which school leavers can prepare and train for their careers. Guidance in the vocational field means helping a person to choose a career, to find a job and to succeed in it (Lindhard, Dlamini \& Barnard 1987:1-7). Career guidance is an umbrella term

I. J.A. Fourie, DLitt. et Phil., is a lecturer in the Department of Information Science, University of South Africa, South Africa 
which can cover progression in learning and work in all its forms, since choices relating to learning and work are closely interwoven (Watts \& Kidd 2000:489). The terms 'career guidance' and 'educational and vocational guidance' will be used interchangeably in this article.

Guidance is an element common to a number of user service functions, namely information provision and reference work, user education, user advice and bibliotherapy. In her model for public library service, Gericke $(2001: 19,225)$ identifies educational and vocational guidance as a form of user guidance. Educational and vocational guidance incorporates interviews and assessment, provision of information and interpretation, advice and counselling, referral, practical assistance and information skills instruction (Butler 1988:14-20; Durrance et al. 1993:20-31; Oakeshott 1991:14; Rawlings 1995:33; Watts \& Kidd 2000:490).

\section{Studies on the provision of educational and vocational guidance and information services in public libraries}

The typical users of educational and vocational guidance and information services (abbreviated as EVGIS) or 'education and job information centres' and 'educational guidance services' as they are also known, have always been adult learners, the unemployed and adults in career transition (Butler 1988: 10; Durrance et al. 1993:viii-ix). The role of the public library in serving adult learners has been the focus of various studies abroad. For instance, research findings on public libraries and the provision of educational guidance services for adults, learners' advisory services and adult independent learners were reported in Carter and Neale (1985), Butler (1988) and Watkin (1995).

An overview of the subject literature reveals that educational and vocational guidance is largely offered to the youth as part of general reference and information and referral services (Willett 1995:70-7I). In addition, large public libraries tend to provide information and referrals to the youth through their websites (Hughes-Hassell \& Miller 2003:I43, I48-I49; Prabha \& Irwin 2003:67). However, a specialised career guidance and information service for high school learners does not appear to be the general rule in public libraries at present. This could be due to the fact that schools and universities are expected to provide relevant career guidance.

Limited research has been conducted in South Africa on the provision of library services to young people seeking educational and vocational information. Gericke (200I:289) found that educational and vocational guidance is offered by most public libraries at various levels to all groups ranging from the provision of information and materials to advice and referral. However, her study did not focus on services to the youth.

The empirical study (Fourie 2006) on which this article is based was aimed at investigating the provision of public library services to the youth in general and EVGIS to high school learners in particular to determine whether these services facilitate learners' access to educational and vocational guidance and information.

\section{Research method}

The study was conducted by means of a questionnaire survey of public libraries in South Africa. It was decided not to select a random sample from the entire population of public libraries but to use the size of a library's collection as a criterion for selecting the survey population, since larger public libraries are in a better position to develop specialised library services. Indeed, the size of a library's collection has traditionally been seen as an indicator of its potential to serve the public (Van Helden \& Lor 2002: I I, I3).

A list of all public libraries in South Africa ranked from the largest to the smallest in order of size of collections was drawn up. The list was based on data in the Public and Community Libraries Inventory of South Africa (PACLISA ) (2002), an updated unpublished version of PACLISA (2004) and the Directory of Southern African libraries (1990). A figure of between 21000 and 22000 volumes (items) was used as the cut-off point for the selection of the survey population. The smallest library that participated in the study had a stock of 21279 items. The survey population comprised 257 public libraries.

One could equate this method of selecting the survey population to purposive sampling, a non-probability sampling method. It involves designating a group (of persons or institutions or other units of analysis) for selection because there is a specific reason to choose a unique sample, or you know they have some characteristics you want to study (Nardi 2003: 108).

Closed (structured) and open (unstructured) format questions were used in the questionnaire. Open questions were mainly used in combination with closed questions, that is, a question was compiled according to structured response options but there was álso an open option (closed and structured-open format). Structured questions are easy to answer and data processing and analysis are facilitated by prior encoding (Schnetler 1989:43).

The questions consisted of multiple-choice options. The multiple-choice questions provided a choice between three or more categories of responses. They pertained mainly to the extent (namely, 'often', 'sometimes' and 'never') with which a particular user guidance service is provided, the provision of staff, facilities, equipment, services and collections 
for particular user groups, and a particular point of view (namely, 'important', 'fairly important', 'not important'). The structured-open formats also included an open category of response, namely 'Other (specify)'. In most questions respondents could select more than one option. Some questions were a checklist of items from which respondents could select the most applicable item in the list. Other types of items included were a ranking and an inventory question.

Cross-tabulations were done based on an analysis of the frequency tables. Cross-indices were used to create composite scores of different variables so that they could be compared. When comparing indices in relation to one another the highest index score is equated to 100. The variable with the highest average value (variable a) was equated with 100 and the values of other nth variables were calculated in accordance with the following formula (Tustin et al. 2005:487-490):

$$
\frac{\bar{n}}{\bar{a}} \times 100
$$

where

$$
\begin{aligned}
& \bar{n}=\text { the average of the variable under consideration and } \\
& \bar{a}=\text { the average of the variable with the highest measure of importance. }
\end{aligned}
$$

In compiling a weighted index the researcher is able to gain a more balanced overall view of individual responses. For instance, in the calculation of an index a greater weight is given to 'often', as opposed to 'sometimes' and 'never'. In each instance, weights of $2, I$ and 0 were used respectively to weigh the relative importance of the three responses given.

A good response rate of $61,9 \%$ (159) was achieved due to sound cooperation with the relevant library directors prior to the posting of the questionnaires. Libraries that participated in the survey were grouped according to the size of their stock into large, medium and small libraries so that each group represented approximately one-third of the 159 participating libraries. The three size groups (large, medium and small) roughly have the same number of respondents.

\begin{tabular}{|c|c|c|c|c|}
\hline \multicolumn{2}{|c|}{ Size } & \multirow{2}{*}{$\begin{array}{l}\mathbf{N} \\
52\end{array}$} & \multirow{2}{*}{$\begin{array}{c}\text { Percentage } \\
32,7\end{array}$} & \multirow{2}{*}{$\begin{array}{c}\text { Stock } \\
<27429\end{array}$} \\
\hline Small & . & & & \\
\hline Medium & . & 53 & 33,3 & $27429-47554$ \\
\hline Large & & 54 & 34,0 & $47555+$ \\
\hline Total & & 159 & 100,0 & \\
\hline
\end{tabular}
Table I shows the number of libraries which responded in each group.

Table I Number of public library responses by size of stock

\section{Results and discussion}

Although the results of the empirical study focus on EVGIS for high school learners, they also pertain to general services to the youth as a whole as these services could form the basis for developing a specialised service to the group.

\subsection{General user services for the youth}

Adequate information provision, user advice and user education services for the youth are prerequisites for an effective EVGIS for high school learners. These user services are supported by staff, collections, facilities and equipment. Collections usually house paper-based, auditory and audiovisual media and information in electronic form. Facilities and equipment could include lending, study and reference areas, shelving, furniture, computer terminals and audio-visual viewing and listening devices. These resources could be set aside for particular user groups.

Respondents were asked to indicate whether separate staff, facilities and equipment, collections and services are provided for children and youth in their libraries. The following groups were distinguished: pre-school children from 0 to 6 years of age, primary school children from 7 to 12 years of age, teenagers from 13 to 18 years of age and young adults from 19 to 25 years of age.

Figure I shows that most public libraries provide separate collections for pre-school children, primary school children and teenagers. Less than two-thirds provide separate collections for young adults. Over half of the respondents provide separate facilities for pre-school and primary school children and separate services for pre-school and primary school children. Separate staff is provided by over one-third of respondents to work with pre-school and primary school children respectively, but less than one-quarter provide separate staff to work with teenagers and young adults. 


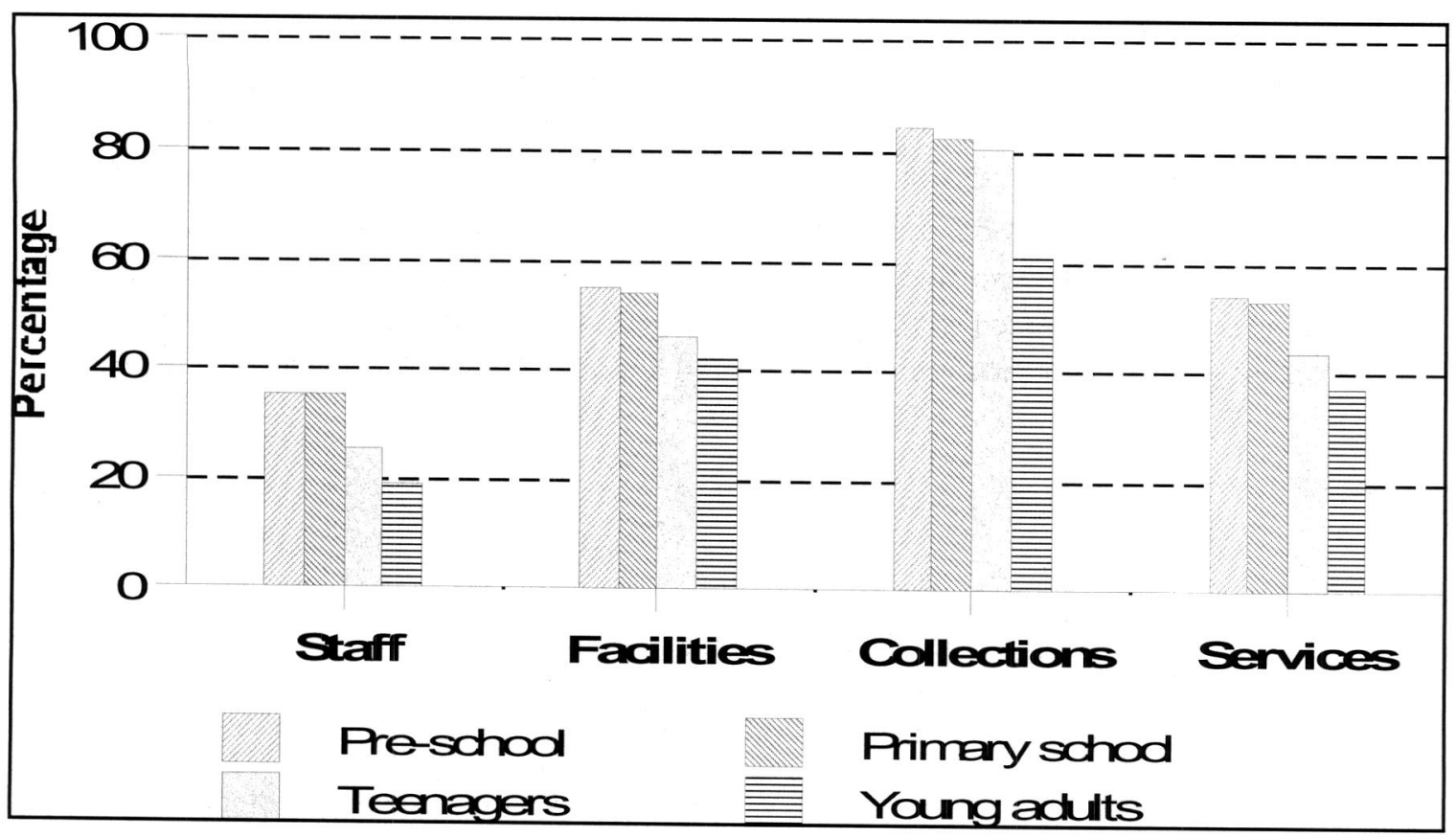

Figure 1 Separate provision of resources and services for children and youth

These results agree with Gericke's (2001:299,307) findings in respect of collections and facilities for these groups. It is clear that separate provision of resources and services decreases as the age of users increases since older groups are able to use collections, facilities, services and staff provided for the general public.

Cross-tabulation of data according to size of stock showed that large libraries are more likely to provide separate resources and services for different age groups while medium-sized and small libraries are less likely to be able to do so.

As career-related enquiries are presented at the reference desk, respondents were asked to indicate which kinds of information service are made available in their libraries to the youth. Most public libraries provide a general reference service $(98,1 \%)$, a reference service to secondary school learners $(86,1 \%)$ and a community information service $(78,5 \%)$. Nearly two-thirds $(63,3 \%)$ offer a reference service for technikon and college students and half $(50,6 \%)$ of the respondents provide a reference service for university students.

User advice embraces guidance in the choice of books and other information sources. The librarian stimulates and facilitates information use by means of various aids and techniques. Respondents were asked to indicate the extent of reading advice provided to the youth in the library. Recommendation of sources is the predominant form of user advice offered. Of the 159 respondents, $69,2 \%$ often recommend sources, $21,4 \%$ sometimes recommend sources and only $9,4 \%$ never do so. The percentages in respect of the production of bibliographies, current awareness bulletins and subject indexes were insignificant.

To enable learners to make independent use of information collections they must be exposed to user education programmes. Respondents were asked to indicate the extent to which various forms of user education and information skills instruction are provided to the youth in the library. The results are shown in Table 2.

Table 2 User education and information skills instruction

\begin{tabular}{|c|c|c|c|c|c|c|c|c|c|}
\hline \multirow{2}{*}{$\begin{array}{l}\text { User education and } \\
\text { instruction in: }\end{array}$} & \multicolumn{2}{|c|}{ Often } & \multicolumn{2}{|c|}{ Sometimes } & \multicolumn{2}{|c|}{ Never } & \multicolumn{2}{|c|}{ Total } & \multirow[t]{2}{*}{ Index } \\
\hline & $\mathbf{N}$ & $\%$ & $\mathbf{N}$ & $\%$ & $\mathbf{N}$ & $\%$ & $\mathbf{N}$ & $\%$ & \\
\hline Library orientation & 102 & 64,2 & 54 & 34,0 & 3 & $\mathrm{I}, 8$ & 159 & 100,0 & 100 \\
\hline Reference source use skills & 104 & 65,4 & 46 & 28,9 & 9 & 5,7 & 159 & 100,0 & 98 \\
\hline Study skills & 17 & 10,7 & 40 & 25,2 & 102 & 64,1 & 159 & 100,0 & 29 \\
\hline Computer skills & 26 & 16,4 & 21 & 13,2 & 112 & 70,4 & 159 & 100,0 & 28 \\
\hline Online search skills & 22 & 13,8 & 27 & 17,0 & 110 & 69,2 & 159 & 100,0 & 28 \\
\hline Use of OPAC skills & 19 & 11,9 & 21 & 13,2 & 119 & 74,9 & 159 & 100,0 & 23 \\
\hline Use of database skills & 11 & 6,9 & 17 & 10,7 & $13 \mid$ & 82,4 & 159 & 100,0 & 15 \\
\hline
\end{tabular}

The data were used to compile a weighted index of the relative importance of the various forms of user education. The formula for calculating the index was explained in section 4. The index appearing in the right-hand column of the table 
shows that the predominant forms of user education offered are library orientation and instruction in reference source use. However, instruction in study skills, computer skills instruction, instruction in online searches, instruction in the use of the OPAC and instruction in the use of databases are seldom offered.

Respondents were asked to indicate how user education and information skills instruction are implemented in their libraries. The majority $(78,4 \%)$ indicated that user education is presented during class visits to the library, individually $(64,1 \%)$, indirectly through pathfinders and learning guides $(39,9 \%)$ and in library visits to schools $(31,4 \%)$

The public library's involvement in user education with school learners appears to be mainly centred on class visits to the library rather than library visits to schools. Hart (2000:74) also found that most public libraries in the Cape Town metropolitan area host primary school classes for library orientation and about one-third offer these services for high schools.

These results show that even in the face of declining resources, public libraries in South Africa continue to provide general reference and other user services to children and youth. These services are the backbone for the rendering of specialised services, such as EVGIS, to specific user groups. They must be put in place before more in-depth levels of service can be developed.

It is clear, however, that due to a lack of resources user services have not developed to their full potential. For instance, information skills instruction could be hindered by a lack of access to computer facilities and the staff required to design the relevant programmes. It remains to be seen whether the existing services already in place are able to render the services required to meet the youths' needs for information and guidance about educational and vocational opportunities and training.

5.2 Educational and vocational guidance and information services for high school learners

Learners' educational and vocational guidance and information needs can be determined indirectly by relying on the reports of reference librarians who deal with their enquiries. Respondents were asked to indicate how often (daily, weekly, monthly, less than once per month) they receive career-related enquiries from school learners in their libraries. Nearly two-thirds $(62,5 \%)$ indicated that career-related enquiries are made by school learners on a daily $(26,8 \%)$ or weekly $(35,7 \%)$ basis.

Respondents also indicated the extent to which enquiries in regard to careers, educational and vocational opportunities and training are made by different groups. Of the 159 respondents, the majority $(76,1 \%)$ indicated that career-related requests are often received from senior secondary school learners, and $19,5 \%$ indicated that they sometimes received career-related enquiries from the group. Only $4,4 \%$ responded in the negative. The frequency of enquiries from junior secondary school learners, unemployed youth and university, technikon and college students is much lower than in the case of senior secondary school learners. The percentages in respect of requests from these three groups were fairly similar to each other. This is clearly shown in Figure 2.

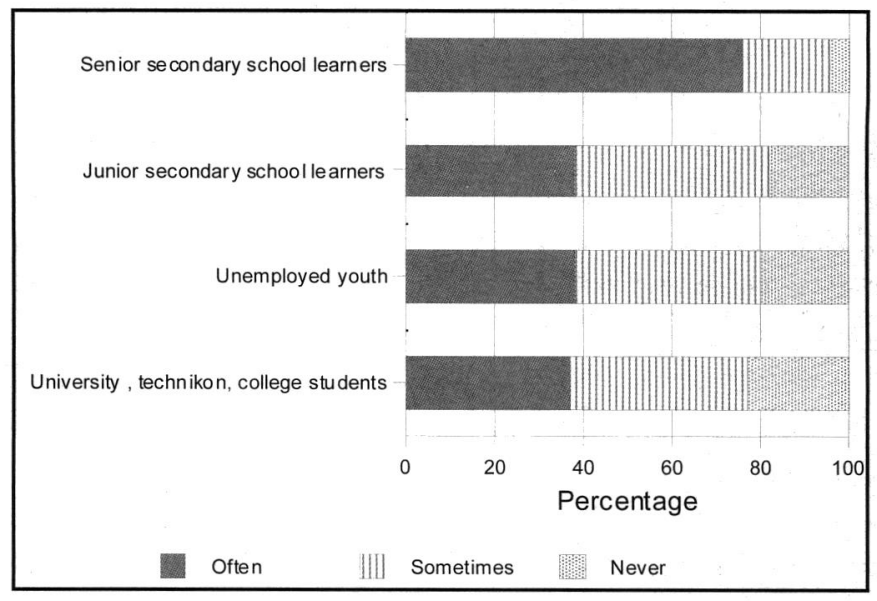

Figure 2 Career-related enquiries by the youth

These results show that junior secondary school learners, unemployed youth and students also have a need for information on employment and educational opportunities. Obviously, junior secondary school learners' needs for this kind of information are not as urgent as the needs of older learners. The percentage of career-related requests of unemployed youth is indicative of the high rates of unemployment among out-of-school youth.

The fact that public libraries are used for the career-related enquiries of the abovementioned groups reflects the gaps existing in organisations and agencies who should be offering these services. Government and non-governmental 
organisations, such as the Employment Service of the Department of Labour, and the National Youth Commission, do not appear to be meeting the needs of the youth in this regard (Potgieter [1999]:38). Unemployed youth in particular are at a disadvantage since they cannot pay the fees which employment agencies and professional private counsellors charge for their services.

As school awareness of public library services is important, respondents were asked to indicate the extent to which career-related requests are received from school counsellors, teacher-librarians and subject teachers. The majority of respondents indicated that school counsellors $(81,8 \%)$ and teacher-librarians $(72,3 \%)$ never make career-related enquiries at the public library. Nearly two-thirds $(64,8 \%)$ of the respondents indicated that subject teachers never do so.

To determine learners' educational and vocational needs, respondents had to select the most important career-related enquiries made by school learners from a list of II topic areas. They were asked to rank the first five topic areas in order of importance on a scale of I to 5. The results are shown in Table 3. All the data were used to compile a weighted index as shown in the right-hand column of the table. In calculating the index the following weights were used to weigh the relative importance of the topic areas ranked by respondents: $5=$ most important, $4=$ second most important, $3=$ third most important, 2 = fourth most important, and I = fifth most important.

Table 3 Career-related enquiries by topic areas

\begin{tabular}{|c|c|c|c|c|c|c|c|c|c|c|c|c|c|}
\hline \multirow[t]{2}{*}{ Career-related topics } & \multicolumn{2}{|c|}{ Most } & \multicolumn{2}{|c|}{ Second } & \multicolumn{2}{|c|}{ Third } & \multicolumn{2}{|c|}{ Fourth } & \multicolumn{2}{|c|}{ Fifth } & \multicolumn{2}{|c|}{ Total } & \multirow[t]{2}{*}{ Index } \\
\hline & $\mathbf{N}$ & $\%$ & $\mathbf{N}$ & $\%$ & $\mathbf{N}$ & $\%$ & $\mathbf{N}$ & $\%$ & $\mathbf{N}$ & $\%$ & $\mathbf{N}$ & $\%$ & \\
\hline University courses & 30 & 27,3 & 19 & 17,3 & 31 & 28,2 & 14 & 12,7 & 16 & 14,5 & 110 & 100,0 & 100 \\
\hline Career planning & 43 & 49,4 & 18 & 20,7 & 5 & 5,7 & 8 & 9,2 & 13 & 14,9 & 87 & 100,0 & 91 \\
\hline Bursaries, grants & 25 & 23,4 & 17 & 15,9 & 21 & 19,6 & 24 & 22,4 & 20 & 18,7 & 107 & 100,0 & 89 \\
\hline Job search skills & 18 & 15,3 & 15 & 12,7 & 33 & 28,0 & 23 & 19,5 & 29 & 24,6 & 118 & 100,0 & 89 \\
\hline Occupations, training & 29 & 31,5 & 15 & 16,3 & 20 & 21,7 & 14 & 15,2 & 14 & 15,2 & 92 & 100,0 & 85 \\
\hline Job opportunities & 12 & 14,8 & 23 & 28,4 & 16 & 19,8 & 18 & 22,2 & 12 & 14,8 & 81 & 100,0 & 68 \\
\hline University entrance & 7 & 8,0 & 23 & 26,1 & 18 & 20,5 & 23 & 26,1 & 17 & 19,3 & 88 & 100,0 & 67 \\
\hline School subjects & 14 & 21,9 & 19 & 29,7 & 12 & 18,8 & 9 & 14,1 & 10 & 15,6 & 64 & 100,0 & 58 \\
\hline Entrepreneurship & 4 & 7,0 & 6 & 10,5 & 13 & 22,8 & 22 & 38,6 & 12 & 21,0 & 57 & 100,0 & 38 \\
\hline Company information & 3 & 13,0 & 3 & 13,0 & 6 & 26,0 & 7 & 30,4 & 4 & 17,4 & 23 & 100,0 & 17 \\
\hline Self-assessment & 2 & 8,0 & 3 & 12,0 & 4 & 16,0 & 7 & 28,0 & 9 & 36,0 & 25 & 100,0 & 16 \\
\hline
\end{tabular}

Number of respondents: 158

Learners' main concerns appear to be the choice of a course of study at a university or college. It is closely followed by concerns about career planning and bursaries, grants and loans. Further needs are employment-related, namely how to search for a job and occupation and training requirements. Requests for information on job opportunities, university entrance requirements and subject choices at school were less important.

Entrepreneurship, company information and self-assessment proved to be the least important topic areas. The apparent lack of importance attached to self-assessment is confirmed by Julien's (1997:157) findings. Her study showed that many adolescents seeking information for career decision-making did not report any need for self-assessment information. They were seeking help to select careers or choose a post-secondary educational institution, without having a clear notion of what their interests, values and skills were. She ascribed this situation to the fact that learners are obliged to select their high school courses, which dictate which college and university programmes they can be accepted into, before they are developmentally ready to do so.

To establish whether adequate resources are available to support EVGIS, respondents were asked to indicate whether separate staff, facilities and equipment, collections and services are provided for career guidance for secondary school learners, students and the general public. As can be seen in Table 4, the percentages in respect of separate provision of career-related resources and services for each group are fairly similar. Well over half of the libraries provide separate career-related collections for each group, whereas separate staff, facilities and services are provided for this purpose by only a small percentage of libraries. 
Table 4 Separate provision for EVGIS for different groups

\begin{tabular}{lcccccc}
\hline \multirow{2}{*}{ Separate provision } & \multicolumn{2}{c}{ High school learners } & \multicolumn{2}{c}{ Students } & \multicolumn{2}{c}{ General public } \\
\cline { 2 - 7 } & $\mathbf{N}$ & $\%$ & $\mathbf{N}$ & $\%$ & $\mathbf{N}$ & $\%$ \\
\hline Collections & 105 & 66,0 & 94 & 59,1 & 104 & 65,4 \\
Services & 29 & 18,2 & 26 & 16,4 & 33 & 20,8 \\
Facilities & 30 & 18,9 & 28 & 17,6 & 29 & 18,2 \\
Staff & 28 & 17,6 & 23 & 14,5 & 27 & 17,0 \\
None & 47 & 29,6 & 56 & 35,2 & 43 & 27,0 \\
\hline
\end{tabular}

Number of respondents: 159

As $29,6 \%$ do not provide separate resources and services for high school learners, one can assume that approximately $70 \%$ make special provision for some form of service or for the resources necessary to support an EVGIS to this group.

The data was also cross-tabulated with libraries according to size of stock. As could be expected, larger libraries provide separate collections, staff, facilities and services for career-related purposes more frequently than medium-sized and smaller libraries.

Respondents were also asked to indicate the kinds of career-related information collections and resources made available in their libraries to school learners. The results are shown in Figure 3. Paper-based information sources predominate as can be seen from the first three categories appearing in the figure. The percentage of libraries which provide access to online career websites, databases of jobs and training providers and self-assessment career software is low. Gericke (2001:285) also reported a fairly low percentage of availability of CD-ROMs, online databases and the Internet for information searches in respect of services to the general public.

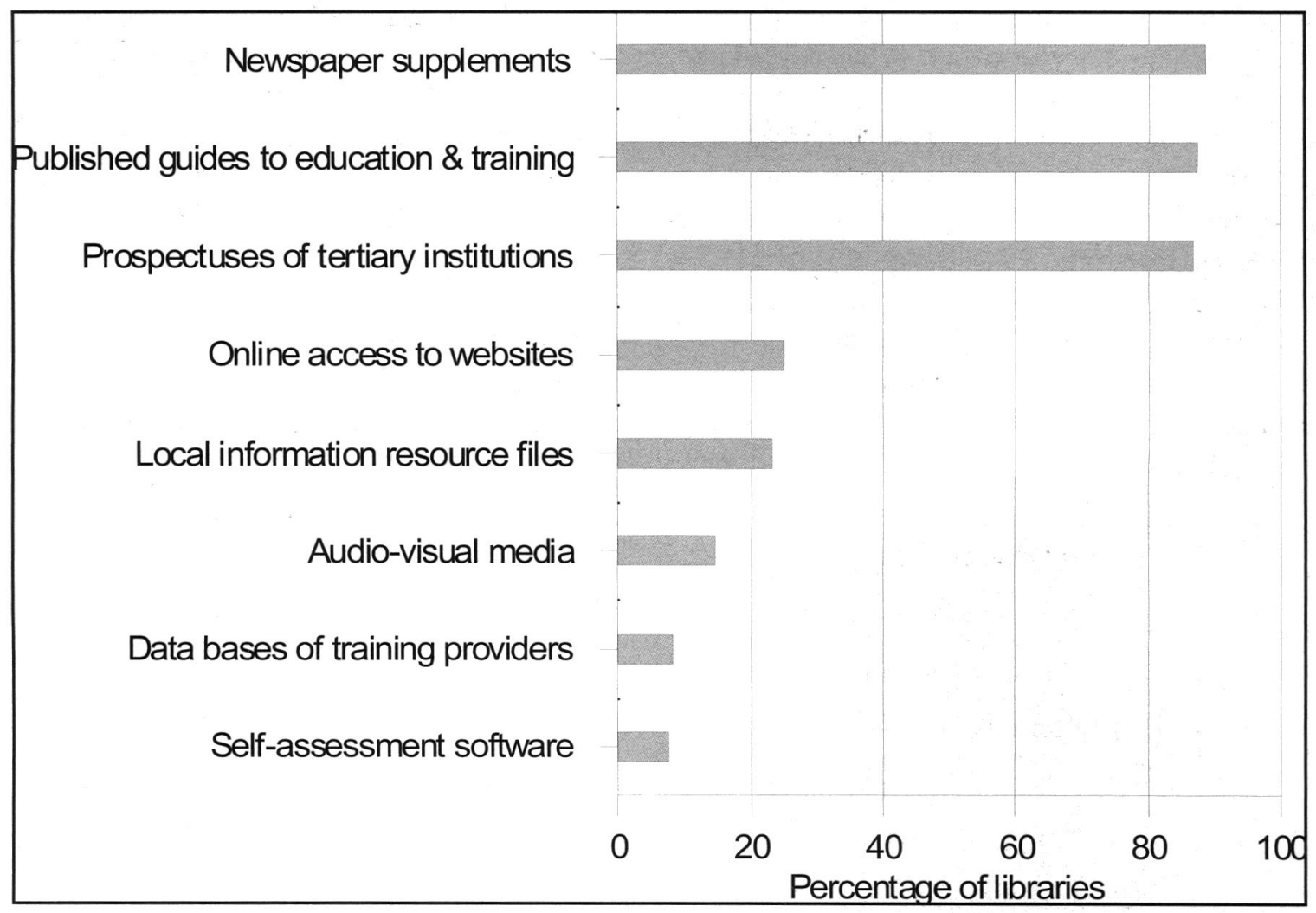

Figure 3 Career-related information collections and sources held by public libraries

The effective rendering of EVGIS to learners involves the various forms of guidance already mentioned in section 2 . Respondents had to indicate the extent to which particular types of guidance are provided to learners in their libraries. The results are shown in Figure 4.

The data on which Figure 4 is based were used to compile a weighted index of the relative importance of the three responses (often, sometimes, never). The results show that educational and vocational guidance in public libraries is mainly focused on directing learners to relevant information sources (100) and the provision of information and information sources (97). This is followed by help in interpreting information and information sources (65), conducting 
reference interviews to answer career-related queries (59) and referrals to outside service providers (57). Advice on educational choices (35) and counselling interviews to assess career information needs (17) is seldom offered.

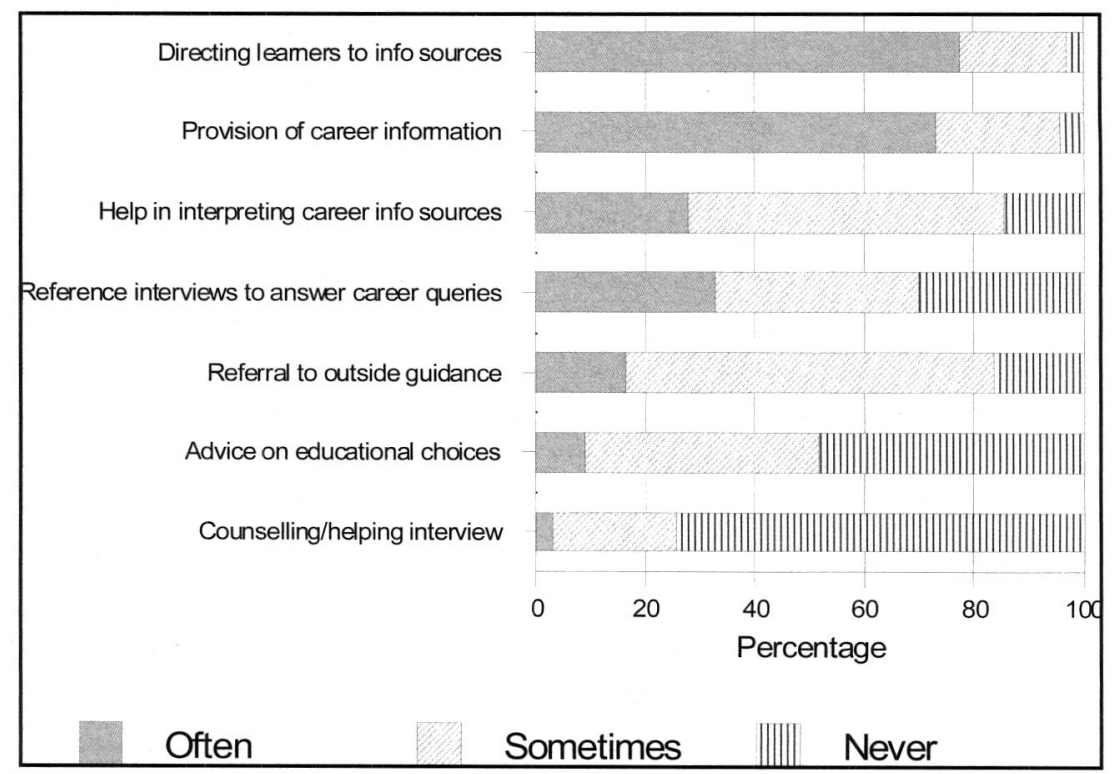

Figure 4 Forms of educational and vocational guidance

The forms of guidance provided may be a reflection of the depth of information required by learners. The majority appear to need only straightforward answers to their queries so that they only need to be directed to the available resources or provided with information. A low percentage appear to have more complex queries. Referral is provided in these cases since the public library cannot meet learners' needs for in-depth guidance.

These results confirm earlier findings abroad that librarians view help in interpreting educational guidance information as part of their guidance functions, but that in-depth advice and counselling is not seen as a professional function since librarians do not have the qualifications required to offer such forms of guidance (Butler 1988:19,87,91-92, 95-97; Childers 1984:26; Howcroft \& Eskill-Blokland 2001:239).

As a total of $133(84 \%)$ of the libraries refer requests to other career guidance service providers, respondents were asked to indicate the individuals or organisations to which they referred school learners for information and guidance. Figure 5 shows that referrals to outside service providers occurs for the most part infrequently. For instance, over half of the respondents indicated that they sometimes refer learners to student advisory services at universities and colleges, whereas nearly one-third indicated that referrals to these services are often made.

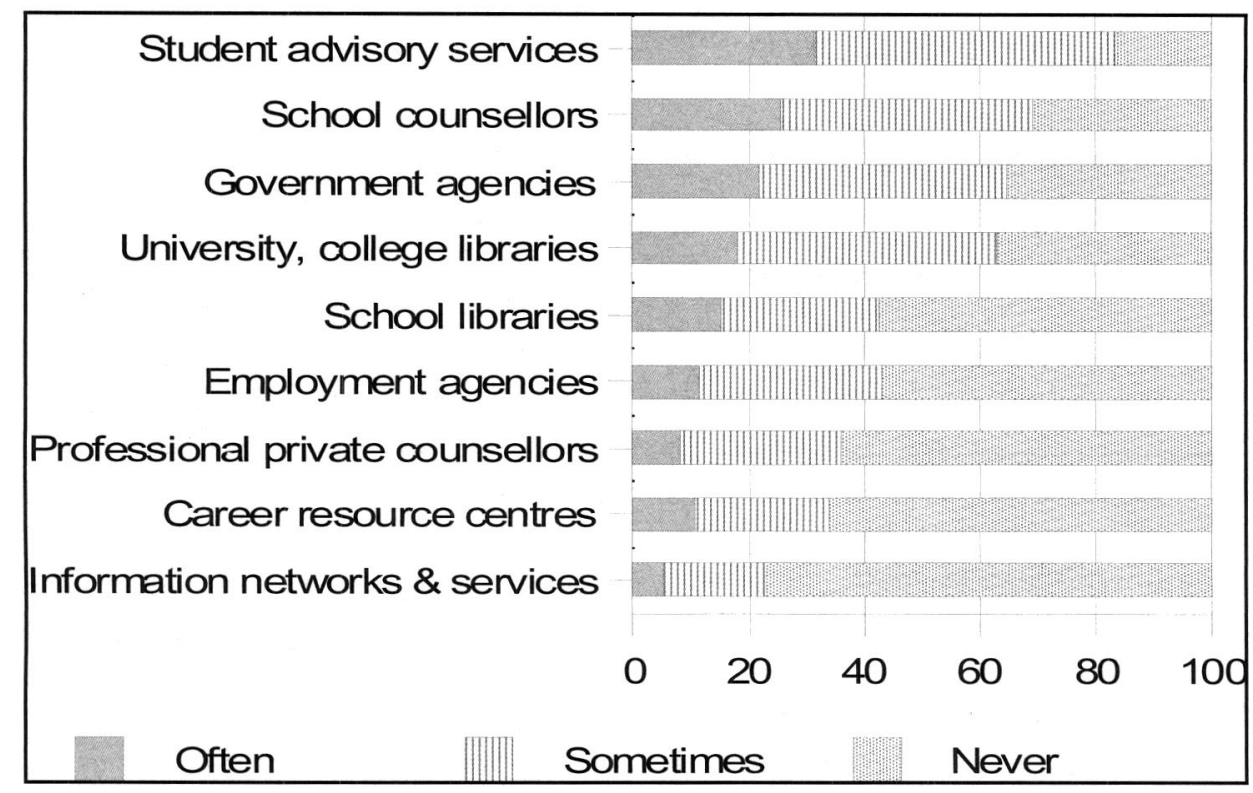

Figure 5 Referrals to career guidance service providers 
The relative importance of the three responses ('often', 'sometimes', 'never') were weighted and the results show that learners are mainly referred to student advisory services at universities and colleges (100), school counsellors and guidance teachers (82), government organisations (75) and university and college libraries (71).

Since public librarians lack the expertise to deal with complex career-related enquiries it is not surprising that there is a high percentage of referrals. However, these referrals involve only a few organisations and individuals outside the library. Librarians do not appear to have built up or maintained networks of organisations and individuals to whom they can refer learners. For instance, approximately two-thirds of the respondents never refer learners to professional private counsellors or career resource centres. This could be due to the fact that these service providers may charge fees for their services or for the use of their facilities, or there may be few individuals or organisations that offer professional advice in the vicinity of the library.

Gericke (2001:289-290) also found that the majority of respondents in her study referred members of the general public to other organisations for vocational and career guidance. Butler's (I988:19) study showed that many librarians view early referral to educational guidance services outside the library as the best option.

Respondents were asked to indicate how frequently they contact service providers to follow up on learners' enquiries, act on behalf of learners, or request feedback about help rendered by service providers to learners. The results show that the majority of public libraries do not attempt to assist learners to implement their career goals outside the library. Those who provide practical assistance do so very infrequently.

These results also confirm the findings of earlier studies abroad that librarians do not view practical assistance (advocacy) as one of their functions and do not engage in follow-up or feedback activities (Butler 1988:19-20, 1II; Childers 1984:27-28).

As effective referral depends on links between libraries and outside agencies and individuals it was necessary to determine whether cooperation between public libraries, schools and other agencies exist.

\subsection{Cooperation between the public library, the school and other service providers}

The public library can share its resources with schools by making sources available for homework assignments, providing study facilities and block loans of library materials for classroom use, or school and public library facilities could be housed together. Respondents were asked to indicate any cooperative services with schools in which their libraries are involved. The results are shown in Table 5.

Table 5 General cooperative services with schools

\begin{tabular}{lcc}
\hline \multicolumn{1}{c}{ General cooperative services } & N & $\%$ \\
\hline Making sources available for homework assignments & 148 & 93,1 \\
Provision of space for studying & 143 & 89,9 \\
Promoting school awareness of public library services & 90 & 56,6 \\
Block loans of materials for classroom libraries & 79 & 49,7 \\
Cooperating with teacher-librarians & 62 & 39,0 \\
Combined public and school library facilities & II & 6,9 \\
Attending school library committee meetings & 5 & 3,1 \\
Other cooperative activities & 6 & 3,8 \\
\hline
\end{tabular}

Number of respondents: 159

The majority of libraries make sources available for homework assignments and provide space for studying. Over one half are involved in promoting school awareness of public library services and nearly one half offer block loans of materials for classroom libraries. As already mentioned in section 5.I, class visits to public libraries and library visits to schools for user education purposes take place fairly frequently. This occurs in spite of the relatively low level of cooperation with teacher-librarians.

Respondents were asked to indicate any career-related extension, outreach or cooperative programmes in which their libraries are involved. The data show that career-related cooperative and outreach activities with schools or any other organisation are not given priority in public libraries. Nearly $50 \%$ of the responses were in the negative in regard to any of these activities.

Of the few libraries which engage in cooperative activities only $5,8 \%$ cooperate with school counsellors. It is not surprising that there is very little cooperation with school counsellors. This result reflects the situation in many schools, namely that they do not have posts for school counsellors or guidance teachers. As commented by one respondent in KwaZulu-Natal 'There are approximately 200 schools in and around our city but only old Model C schools have school 
counsellors'. A comment from a librarian in the Western Cape appears to support this statement. 'Most schools in this predominantly white area, have well-stocked libraries and school counsellors'.

These comments seem to suggest that some former Model C schools have retained their school counsellors' posts but that other, less privileged, public schools lack provincial or national government support to maintain school guidance teachers to initiate such a programme. In addition, the important role played by school counsellors in meeting learners' educational and vocational guidance and information needs are underlined by these statements.

This result supports findings reported in the subject literature which show that public library youth services are not as active in their support of community agencies as they are with schools and that only a small percentage of public libraries work cooperatively with school guidance counsellors (Boatman 2003:230; Willett 1995:68-69).

Most public libraries support the formal educational needs of school learners and the public library supplements school library resources because it has more comprehensive collections. If links with schools could be fostered, a network of career guidance service providers could be developed. However, if there is no teacher-librarian or school counsellor it is difficult to see how such a network can be initiated.

It is clear that services are not provided at an in-depth level. Most libraries lack the required number of staff to fully develop and maintain either general user services to children and youth or EVGIS to high school learners. It was necessary to determine whether a lack of staff or any other factors in the internal and external environment of public libraries are hindering the development of educational and vocational guidance services to learners.

5.4 Barriers to the delivery of educational and vocational guidance and information service to learners

Various internal and external factors affect the rendering of library and information services. Internal factors are the availability of library resources, namely, collections, facilities, funding and staff. External factors are the educational, economic and cultural environment. Respondents were asked to indicate the importance of the factors that restrict the delivery of a career guidance and related information service to school learners. The results are shown in Table 6.

Table 6 Barriers to the provision of EVGIS to learners

\begin{tabular}{lccccccccc}
\hline \multirow{2}{*}{ Factors } & \multicolumn{2}{c}{ Very important } & \multicolumn{2}{c}{ Fairly important } & Not important & \multicolumn{2}{c}{ Total } & Index \\
\cline { 2 - 8 } & $\mathbf{N}$ & $\%$ & $\mathbf{N}$ & $\%$ & $\mathbf{N}$ & $\%$ & $\mathbf{N}$ & $\%$ & 100 \\
\hline Lack of funds & $\mid 17$ & 79,6 & 21 & 14,3 & 9 & 6,1 & 147 & 100,0 & 100 \\
Lack of qualified staff & 77 & 53,8 & 44 & 30,8 & 22 & 15,4 & 143 & 100,0 & 80 \\
Lack of community support & $4 \mid$ & 31,8 & 52 & 40,3 & 36 & 27,9 & 129 & 100,0 & 60 \\
Low income levels & 37 & 29,8 & 34 & 27,4 & 53 & 42,7 & 124 & 100,0 & 50 \\
Low education levels & 32 & 26,0 & 39 & 31,7 & 52 & 42,3 & 123 & 100,0 & 48 \\
Cultural differences & 22 & 17,6 & 44 & 35,2 & 59 & 47,2 & 125 & 100,0 & $4 \mid$ \\
\hline
\end{tabular}

Number of respondents: 151

The data in Table 6 were used to compile an index. In this instance, weights of 2, I and 0 were used to weigh the relative importance of the three responses. Lack of funds is viewed as the most important factor influencing the provision of EVGIS to learners with lack of qualified staff as the second most important factor. Lack of community support, low income and educational levels and cultural differences are not viewed as significant barriers to the development of EVGIS.

Problems in the appointment of qualified staff were underlined by the comments in answer to the open question. Respondents were asked to mention any important points about career guidance and information services in public libraries that came to mind. Many of these comments pertained to a lack of qualified staff but also to a lack of funds and up-to-date information sources. Lack of staff time and lack of relevant sources were mentioned by $11,3 \%$ and $12,6 \%$ of respondents respectively.

The crisis in the funding and management of public libraries brought about by unfunded provincial control is well documented (Gericke 200I:27I-275; Wilckens 2005). As a result, libraries have suffered severe losses of staff with resulting negative effects on the quality of services. A lack of staff means that there is a lack of time to provide an individual service. As commented by one respondent 'Library staff rotate on counter service, one doing information requests'. A major need is not only for more staff but for staff with qualifications which match the needs of new libraries (Anderson 2005:15).

A public library which renders EVGIS requires staff with relevant qualifications. Respondents were asked to indicate the importance of professional Library and Information Science qualifications, further education and in-service training for career guidance and information service provision in public libraries. The results are shown in Table 7 with the calculated index in the last column. 
Table 7 Librarians' views on the importance of LIS and career guidance qualifications for staff

\begin{tabular}{|c|c|c|c|c|c|c|c|c|c|}
\hline \multirow{2}{*}{ Staff training } & \multicolumn{2}{|c|}{ Very important } & \multicolumn{2}{|c|}{ Fairly important } & \multicolumn{2}{|c|}{ Not important } & \multicolumn{2}{|c|}{ Total } & \multirow[t]{2}{*}{ Index } \\
\hline & $\mathbf{N}$ & $\%$ & $\mathbf{N}$ & $\%$ & $\mathbf{N}$ & $\%$ & $\mathbf{N}$ & $\%$ & \\
\hline Professional LIS qualifications & 84 & 56,0 & 46 & 30,7 & 20 & 13,3 & 150 & 100,0 & 100 \\
\hline In-service career guidance training & 69 & 46,6 & 64 & 43,2 & 15 & 10,1 & 148 & 100,0 & 96 \\
\hline Formal further education in career guidance & 47 & 32,4 & 68 & 46,9 & 30 & 20,7 & 145 & 100,0 & 78 \\
\hline
\end{tabular}

Number of respondents: 154

The majority of librarians regard professional LIS qualifications and in-service career guidance training as relatively more important for the delivery of an EVGIS than formal further education in the career guidance field.

\section{Recommendations and conclusion}

\subsection{Collections, facilities, staff and funds}

Public libraries will have to subscribe to electronic career development tools and computer-based career guidance and information systems available online and on CD-ROM. CV databases and electronic job postings are also available on the Web. Libraries should be linked to the Internet and acquire the necessary computer facilities. Access to electronic resources will ease the burden on overworked staff and enable them to cope with learners' demands more efficiently.

Many public libraries lack the resources to develop separate services. In large public library systems a member of staff with sole responsibility for collections and services for the youth could coordinate the development of an EVGIS for high school learners. In medium-sized and smaller libraries, the collections and services for young people should be housed in a separate area with separate facilities and collections for an EVGIS. Career-related collections and facilities for the adult general public could also be developed and extended for use by high school learners.

The availability of qualified staff is a prerequisite for specialised services and this is dependent on adequate financial resources. The RI billion that the South African government is to invest in libraries should stop the deterioration of public libraries in the short-term (Bonthuys 2006:2). However, a long-term solution will only be achieved once the uncertainties regarding provincial funding and the organisational structure of public libraries have been fully addressed.

\subsection{Staff development and training}

Post-secondary education is very complex. If EVGIS are to be developed, then Library and Information Science training should furnish prospective librarians with knowledge about educational and employment opportunities and requirements in different career fields. Knowledge about the number of subjects, types and levels of qualifications, different modes of attendance at tertiary institutions and fees and grant structures is also essential.

The facilitating and guidance functions required of librarians working in an EVGIS should be recognised in training courses. Librarians will have to be trained either formally or in-service to be able to conduct helping interviews to assess needs. They will then be in a position to decide whether the learner should be referred to a professional counsellor. Librarians could enrol for formal certificate courses in career guidance to supplement their professional qualifications.

\subsection{Organising networks}

By developing and maintaining a network of guidance to the learner, the librarian will ensure effective referral. Public libraries can establish a system of communication with school counsellors and professional counsellors in private practice to offer a referral service for individual counselling. Librarians should also form partnerships with guidance groups in the public and private sector. They could cooperate with career resource centres and student advisory services in offering career workshops as part of an educational support programme.

\subsection{Services}

In planning services public libraries will have to make decisions on the following aspects:

- how existing services can be extended to introduce new services

- the forms of educational and vocational guidance that can be incorporated into the existing framework of user services

- how to cooperate with other service providers in order to ensure a complete EVGIS to the youth.

\subsection{Existing services}

Existing reference and community information services for the general public as well as specific reference services to secondary school learners and students could provide a springboard from which a specialised EVGIS to high school learners could be developed.

SA JnI Libs \& Info Sci 2007, 73(I) 
As more resources become available services can be expanded. As higher levels of service are reached, more in-depth guidance can be offered. For instance, a library that delivers a career reference service making use of regular staff could initiate an EVGIS. The career information collection could be relocated to a separate area and a qualified staff member who has undergone training as a lay career guidance practitioner could be appointed.

The introduction of EVGIS requires the adoption of a more active approach to service rendering. If the library gives priority to a self-help service rather than individual guidance, it should be supported by network organiser activities, production of current awareness bulletins, indexes and bibliographies and instruction in information skills. This will entail improving user advisory and user education services which are not fully developed at present.

\subsubsection{Forms of educational and vocational guidance}

Interviews and assessment, information provision and interpretation, information skills instruction, advice, counselling and referrals can be accommodated within the framework of existing library and information services for young people.

The learner's first encounter with the service will be in an interview in which the librarian assesses his or her needs. The young person's skills in regard to reading and computer use should be evaluated. This will enable the librarian to direct the learner to appropriate sources. The librarian can conduct individual assessments to link the personal qualities of the learner with possible career fields, provided he or she has undergone the necessary training. Interactive career assessment software could be made available for self-assessment by the learner but it takes one hour of uninterrupted time. Appointments would have to be made if the learner wishes to make use of the relevant library facilities on his or her own.

The public library should facilitate access to educational and career information by ensuring that it is presented in a usable format and language, or repackaged so that it is adapted to the purpose for which it is required. Staff can compile a separate local information file on careers, educational and job opportunities.

Information skills instruction programmes for learners who have to be assisted in interpreting and evaluating paperbased and web-based textual information should be developed. The programme would necessitate collaboration between the public librarian, teacher-librarian and school counsellor.

Librarians need to develop skills in advising learners about career options and facilitating decision-making. With additional knowledge about educational requirements and routes to qualifications the librarian will be able to deliver an advisory and facilitating service. In-depth interviews are required where the young person experiences indecision about careers. However, librarians do not have the qualifications to counsel learners on personal problems since expert training is required for this. Should the librarian detect a problem the learner should be referred to a qualified counsellor.

\subsubsection{Cooperation}

To fully develop cooperative and outreach services the librarian should promote school awareness of public library services and cooperation with teacher-librarians. Most public libraries ensure that sufficient resources are made available for school assignments through informal contacts with school staff. On this basis a system of formal communication between schools and public libraries should be initiated and developed.

Although the results show that cooperation between public libraries and other career guidance service providers is below $50 \%$ at present, public libraries should attempt to form partnerships with guidance groups and organisations in the public and private sector. One particular government or non-governmental body should coordinate activities and disseminate career information. A network of service providers could ensure that out-of-school youth and high school learners in disadvantaged communities who do not have recourse to school counsellors, career resource centres or school libraries are provided with educational and vocational guidance and information.

\section{References}

Anderson, E. 2005. Public libraries in a woeful state. LIASA-in-touch, 6(2):15.

Boatman, W. 2003. Public libraries as a bridge for college-bound young adults. Reference and User Services Quarterly, 42(3):229234.

Bonthuys, J. 2006. 'n Miljard aan biblioteke bewillig. Naweek-Beeld, Saterdag II Februarie:2.

Butler, L. 1988. The role of public libraries in the provision of educational guidance for adults. Boston Spa, Wetherby: British Library Board. (Library and information research report, 22).

Carter, J \& Neale, B. 1985. Education, information, libraries and learners. Bradford, West Yorkshire: MCB University Press Limited. (Library management, volume 6 no 3).

Childers, T. 1984. Information and referral: public libraries. Norwood, NJ: Ablex Publishing Corporation.

Directory of Southern African libraries, 1989. 1990. Pretoria: State Library.

Durrance, JC. et al. 1993. Serving job seekers and career changers: a planning manual for public libraries. Part of the Public Library Development Program. Chicago: American Library Association.

Fourie, JA. 2006. Educational and vocational guidance and information for the youth in public and community libraries. D.Litt et Phil. thesis, University of South Africa, Pretoria. 
Gericke, EM. 200I. Dienslewering in die openbare biblioteek met spesiale verwysing na gebruikersleiding. D.Litt. et Phil.-tesis, Universiteit van Suid-Afrika, Pretoria.

Hart, G. 2000. A study of the capacity of Cape Town's children's librarians for information literacy education. Mousaion, I8(2):67-84.

Howcroft, G \& Eskell-Blokland, L. 200I. Ethical issues, in Counselling in Southern Africa: a youth perspective. Editors E Van Niekerk, A Prins. Johannesburg: Heinemann:218-243.

Hughes-Hassell, S \& Miller, ET. 2003. Public library websites for young adults: meeting the needs of today's teens online. Library \& Information Science Research, 25:143-I56.

Human, B. 1992. Rol van die mediasentrum in die skool met besondere verwysing na integrering met skoolvoorligting. M.Ed.tesis, Universiteit van die Oranje-Vrystaat.

Jennings, R. et al. 1997. The situation of youth in South Africa. Johannesburg: Community Agency for Social Enquiry.

Julien, HE. 1997. How does information help? The search for career-related information by adolescents. D.Phil., University of Western Ontario, London, Ontario.

Kruger, J. 1995. Youth marginalization in South Africa: economic perspectives. Stellenbosch: Stellenbosch Economic Project, Centre for Contextual Hermeneutics, University of Stellenbosch. (Occasional papers no 12).

Lindhard, N, Dlamini, N \& Barnard, W. 1987. Guidance in the classroom. 3rd edition. Cape Town: Maskew Miller Longman.

Lor, PJ. 1998. Memorandum on the state of libraries in South Africa, March 1998. The LIASA Letter: newsletter of the Library and Information Association of South Africa, 2(I):7-12.

Molefe, ORD. 1994. School guidance and multi-modal counselling for secondary school students. Ph.D. thesis, University of Pretoria.

Moolla, N. 1996. Reconstructing educational psychology in the South African context: school systems consultation as a dimension of service delivery. M.Ed. thesis, University of Cape Town.

Naidoo, V. 1997. The role of information skills, curriculum resource material and education library and information services in Curriculum 2005. Mousaion, I5(2):3-9.

Nardi, PM. 2003. Doing survey research: a guide to quantitative methods. Boston: Pearson Education, Inc.

Oakeshott, M. 1991. Educational guidance for adults: identifying competencies. London: Further Education Unit.

PACLISA. 2002. Pretoria: National Library of South Africa. (CD-ROM).

PACLISA. 2004. Centre for Geoinformation Science, University of Pretoria. (Unpublished electronic databases, accessed I5 September 2004).

Potgieter, F, [1999]. Accelerate change: youth development and the next five years. Youth Development Journal, 2:30-44.

Prabha, C \& Irwin, R. 2003. Web technology in public libraries: findings from research. Library hi tech, 2I(I):62-69.

Public and Community Libraries Inventory of South Africa see PACLISA.

Quality education for all, overcoming barriers to learning and development: report of the National Commission on Special Needs in Education and Training (NCSNET) and National Committee on Education Support Services (NCESS), Department of Education, Pretoria, 28 November 1997. 2003. Pretoria: Department of Education. Also available:<http://wwweducation.gov.zal index.asp?src $=r$ sea $>$ (accessed I June 2004).

Rawlings, J. 1995. Stock selection and management, in Supporting adult learners, edited by AL Bamber with contributions from $\mathrm{R}$ Aldrich, A Watkin, D Barker, J Rawlings. London: Library Association:31-38.

Schnetler, J. 1989. Principles of constructing questions and questionnaires, in Survey methods and practice, J Schnetler (ed.), DJ Stoker, BJ Dixon, D Herbst, E Geldenhuys. Pretoria: Human Sciences Research Council, Opinion Survey Centre:43-49.

Tustin, DH. et al. 2005. Marketing research in practice. Pretoria: Unisa Press.

Van Helden, P \& Lor, PJ. 2002. Public and community libraries inventory of South Africa: PACLISA final report. Project of the Print Industries Cluster Council Working Group and the Foundation for Library and Information Service Development ... Pretoria: National Library of South Africa.

Van Niekerk, S. 2002. Voorligting wesenlik in skole. Beeld snuffelgids, Woensdag II Desember:3.

Van Zyl Slabbert, F. et al. 1994.Youth in the new South Africa, towards policy formulation: main report of the Cooperative Research Programme, South African youth. Pretoria: Human Sciences Research Council.

Watkin, A. 1995. Staff training and development, in Supporting adult learners, edited by AL Bamber with contributions from R Aldrich, A Watkin, D. Barker, J Rawlings. London: Library Association: I5-23.

Watts, AG \& Kidd, JM. 2000. Guidance in the United Kingdom: past, present and future. British Journal of Guidance \& Counselling, 28(4):485-503.

White, M \& Wilson, P. 1997. School counselors and teacher-librarians: a necessary partnership for effective schools. Emergency Librarian, 25(I): I-II. Also available: <http://web9.epnet.com/citation > (accessed $7^{\text {th }}$ May 2004)

Wilckens, S. 2005. The future of public and community libraries: implications of the Municipal Structure Act [prepared on behalf of LIASA]. (Unpublished).

Willett, HG. 1995. Public library youth services: a public policy approach. Norwood, NJ: Ablex Publishing Corporation. 


\title{
An overview of electronic information resources sharing initiatives in Kenyan universities
}

\author{
Daniel C. Rotich' \\ Department of Publishing and Media Studies, School of Information Sciences, \\ Moi University, P.O. Box 3900, Eldoret, Kenya. \\ dcrotich@hotmail.com
}

and

Evans M. Munge ${ }^{2}$

Moi University library, P.O. Box 3900, Eldoret, Kenya.

mungemwangi@yahoo.co.uk

\begin{abstract}
Received: 5 th June 2006
Accepted: 10th November 2006

Information professionals in Kenya have long been cognisant of the need to share and transfer information among themselves. Unfortunately, information resource sharing initiatives have been limited to inter-library loans (ILL) ventures which have also not been very successful. Some of the reasons for failure have been: insufficient information resources for sharing, inadequate budget allocation to cater for the high costs of information resources, and the lack of appropriate communication infrastructure and enabling technologies to support any meaningful venture considering that most libraries in Kenya have been operating on manual systems.

The widespread use of information and communication technologies (ICTs) in Kenya since the 1990s has, however, enabled the realisation of a number of information sharing initiatives among libraries and information centres. This paper examines successes and/or failures of such initiatives among Kenyan universities in relation to the objectives for which they were intended to fulfil, arguing that progress can be achieved much more easily by focusing future efforts toward building on the successes, and avoiding the pitfalls that have been experienced.

It is concluded that although on-line information sharing networks are not a panacea to all the problems facing information providers in Kenyan universities, they have, nevertheless, potential to open new avenues, enabling users to have access to vast information resources available within national and international databases, as a way of alleviating information scarcity in these institutions.
\end{abstract}

Key words: Kenya, information resources sharing, information networking

\section{Introduction}

Resource sharing, while seen in the context of librarianship, is an omnibus expression to cover co-operation, coordination, inter-library loans, co-operative acquisitions, co-operative storage and processing (Odini, 1991). Following this reasoning it can be argued that information resources sharing is a wide phrase embracing information services cooperation, systems, and networking. This is in agreement with Odini's ( $|99|$ ) assertion that resource sharing may be seen as a term for working out inter-institutional relationships for the benefit of users in a profession which is frequently described as changing from materials-oriented to client-oriented.

Information professionals in Kenya realized that they can not manage to acquire all the information resources their institutions require, and also, as a result of the information explosion, the amount of information generated is so enormous as to render its complete collection by one institution impossible. Hence the need to share and transfer information among themselves. Unfortunately, information resource sharing initiatives in Kenya's libraries and information centers have been limited to inter-library loans (ILL) ventures mostly among libraries of similar genealogy (for example, special libraries, academic libraries, and so on), and even these have had more failures than successes.

Among the reasons for failures have been: lack of institutional policies or obligations relating to resource sharing, insufficient information resources for sharing, inadequate budget allocation to cater for the high costs of resources, and lack of appropriate communication infrastructure and enabling technologies. In other words, there has been inefficient application of the concept of resource sharing in Kenya (Were, 2004).

This paper provides an overview of the current situation of existing initiatives, focusing especially on their successes and/or failures in relation to the objectives which they were intended to fulfil, so that in future efforts will be focused

I. Daniel Rotich, PhD, is Head of the Department of Publishing and Media Studies, School of Information Sciences, Moi University, Kenya.

2. Evans Munge is Librarian, Moi University Library, Moi University, Kenya. 
toward building on the successes and avoiding the pitfalls that have been experienced. Much of this information has been garnered from the authors' own experiences, either as information services providers or as information sciences educators in the Kenyan university scene, backed by information available in the professional literature and also from contacts within the library and information science network in Kenya.

\section{Overview of universities in Kenya}

In the context of this paper, universities are those institutions have been authorized to offer university education in Kenya through accreditation by the Commission for Higher Education (CHE). According to CHE (2006), Kenya currently has 23 universities, of which 6 are public (that is, those established by Acts of Parliament) and the rest are private. The public chartered universities are:

- University of Nairobi. Established in 1956 as the Royal Technical College, it became the first national university in Kenya in 1970. It is the largest university in the country;

- Moi University. It was established in 1984 as the second public university in Kenya. It also has a constituent college, the Western University College of Science and Technology (WUCST), which was established in 2002;

- Kenyatta University. Established in 1965 as Kenyatta College, offering courses in secondary and teacher education. It was made a full-fledged university in 1985;

- Egerton University. It was founded in 1939 as a school for training white European youth for careers in agriculture. It achieved university status in 1987;

- Jomo Kenyatta University of Agriculture and Technology. It started operations in I98I as a diploma awarding institution in the fields of agriculture and engineering. It became a full-fledged university in 1994, and

- Maseno University. Began as a government training institute in the 1980s, became a constituent college of Moi University before achieving full university status in 2001 .

The private universities are those established in accordance with the Universities Act, 1985 and University Rules, 1989. They fall into three categories: chartered, registered, and universities operating under Letters of Interim Authority. The private chartered universities (and the years they were granted charters) are: University of Eastern Africa, Baraton (1978); Catholic University of Eastern Africa (1992); African Nazarene University (1993); Daystar University (1994); Scott Theological College (1997); United States International University (1999); Aga Khan University (2002), and Kenya Methodist University (2006).

The registered universities are those that were offering degrees before the establishment of CHE and were issued with a Certificate of Registration after fulfilling the requirements set out in the Universities Rules, 1989. These institutions, which were all registered in the 1980s, are: the Kenya Highlands Bible College; the Nairobi Evangelical Graduate School of Theology; the Nairobi International School of Theology; the Pan Africa Christian College, and St Paul's Theological College. $\mathrm{CHE}$ is working with these institutions towards the award of charters.

The universities operating under Letters of Interim Authority are those that have applied to CHE for their establishment and fulfilled requirements as stipulated in the Universities Rules, 1989, even though they are yet to be awarded charters. All these were either established or upgraded to university status between 2000 and 2002, and are Kabarak University; Kiriri Women's University of Science and Technology; Strathmore University, and the East African School of Theology.

The majority of these institutions are located in Nairobi Province ( 2 public and II private), followed by Rift Valley ( 2 public and 4 private), Central Provice (I private and I public). Nyanza and Eastern each have one, public and private respectively.

\section{Information resources sharing in the electronic age}

With the widespread use of computers and related technologies in Kenya in the 1990s, information processing organisations began to use information and communication technologies (ICTs) to enhance the hitherto moribund information resource sharing initiatives. Several factors have contributed to the need for electronic networks for on-line information sharing in Kenya.

One of these is the critical need for access to, and sharing locally and internationally available information resources. The increase in the value and demand of information which continues to exert pressure on libraries to offer more effective service to their users, has also been gradually leading to a shift in focus from the need for accumulation and ownership of information resources to providing access (Wanyoike, 2004).

There has also been the recognition and appreciation, as in information environments in other parts of the world, of the emergence of a sophisticated 'new' class of clients with diverse information needs that require to be satisfied (Ocholla, 1995). Information processing organisations in Kenya have thus been compelled to use new technologies such as ICTs to enhance service delivery, especially through information sharing.

SA JnI Libs \& Info Sci 2007, 73(I) 


\section{Existing collaborative information networks}

ICTs have enabled a number of information sharing initiatives among Kenyan universities, most of which proliferated in the 1990s and early 2000. In many of the universities, the services provided by the initiatives are channelled through the university libraries as opposed to the university as a whole. This is due to a number of reasons.

First, the university libraries have been more directly involved in the initiation and implementation of the initiatives, and therefore they are seen as the 'natural' home of the initiatives. Secondly, libraries are the most centrally located to provide facilities where majority of the university community can access the e-resources. Thirdly, the majority of the target users do not have adequate search (as well as ICT) skills to enable them fully exploit these resources, and so they look up to the library staff to provide this expertise.

This section provides a brief profile of the major networks that have had a big impact on information resources sharing and a description of the level of their collaboration.

The African Virtual University

The African Virtual University (AVU) was launched in 1997 through World Bank funding. Its objective is to provide students and professionals in Africa with access to some of the highest quality learning resources from around the world through the use of modern information and communication technologies (AVU, 2005). This 'university without walls' has been using satellite technology to deliver distance education at over 57 learning centres in 27 African countries. This has enabled higher education institutions to supplement their existing programmes with resources of a global virtual university.

In Kenya, Kenyatta and Egerton Universities are the key institutions participating in this undertaking, which by 2003 had evolved from a project of the World Bank to an independent non-profit making organization with headquarters in Nairobi, Kenya. Other universities, however, are also working towards integrating the AVU into their programmes. For example, Moi University has recently appointed a senior member of staff to spearhead the rollout of the AVU programme in the institution. There is no doubt that this trend will catch on quite fast as institutions of higher learning in Kenya realise that the use of ICT tools for learning and teaching, especially in distance education, is likely to become more widespread. This will necessitate students and faculty becoming more and more exposed to online information resources.

The African Virtual Library - Kenya

The African Virtual Library - Kenya Chapter (AVL-K) was launched in 1999 as the African Virtual Library Initiative (AVL-I) by a forum of stakeholders - librarians and information technology specialists in Kenyan institutions - meeting under the auspices of the Kenya Institute of Management (KIM). The mission of the African Virtual Library Initiative (AVL-I) itself is

to facilitate the provision of bibliographical and other information online services that meet the needs of educational, research and development work in Eastern Africa, with a view to developing linkages with other regional initiatives to create a truly African virtual library (Internet Foundation of Kenya, 2002).

Against this background, AVL-K was born with the aim of supporting Kenyan libraries' automation, Internet connectivity and networking in order to mobilize the partners (mainly academic and public libraries) to convert their resources into electronic format for online information sharing partnership. Some of the programme's objectives that have a bearing on information resources activities include:

- Assisting libraries to automate and put their holdings in an MARC format to aid in establishing a web-based union catalogue;

- Training in IT skills to enable personnel in member institutions to participate fully in the information technology environment, and

- Promoting networking among the participants for the purpose of on-line information sharing (Wanyoike, 2004).

Currently, the AVL-K project has 30 stakeholders, comprising institutions of higher and intermediate education in the public and private sector, public libraries and documentation centres, and research institutions, among others. All the chartered universities are members of AVL-K. These stakeholders are involved in several activities which are intended to help AVL- $K$ achieve its objectives, among them the following:

- Automating libraries in order to facilitate networking for online information sharing;

- Converting library catalogue records to conform with agreed MARC format to help in establishing an electronic union catalogue;

- Formulating electronic information sharing policy guidelines;

- Establishing sustainable Internet/e-mail connectivity;

- Establishing institutional websites, and

- Planning for the development of community information centres that can be used to transfer information to rural areas in Kenya. 
Kenya National Education Network

The Kenya Education Network (KENET) is part of the U.S. government-funded Leland Initiative that works to extend full Internet connectivity to African countries in order to promote sustainable development. KENET's goal is to:

establish sustainable communication and networking among educational institutions in Kenya that will facilitate wide use of Internet technology in teaching, research and sharing of other information resources to the general populace at affordable cost (KENET, 1999).

The Leland Initiative Memorandum of Understanding was signed in 1999 between the Kenya and US governments mandating the Initiative to establish and enhance Internet services for education and to promote information resources sharing among stakeholders for the benefit of the academic community in Kenya. In this respect, the project's goal is highly consistent with AVL-K's core objective of networking Kenyan libraries for the purpose of on-line information sharing (Wanyoike, 2004).

The broad objectives of the project (KENET, 1999) include:

- Setting up a cost-effective and sustainable private network with high-speed access to the global Internet;

- Facilitating electronic communications among students and faculty in member institutions;

- Sharing teaching and learning resources;

- Providing a platform and infrastructure for electronic teaching and learning, and

- Collaborating in research and development of educational content.

In order to fulfil these objectives, KENET began by applying and being granted a licence by the Communications Commission of Kenya to build and operate an education network, and further to operate as an Internet Service Provider (ISP). This means that KENET, whose secretariat is located at the University of Nairobi's Jomo Kenyatta Memorial Library, could establish and manage its own private network to carry both voice and data.

KENET was designed to have a very wide focus comprising universities, professional training institutes, post secondary training institutions, schools, research institutes and libraries, with Telkom Kenya (a government owned parastatal with monopoly in telecommunication business) as a facilitating partner. Indeed, by the end of 2004 this electronic network had managed (with donor funding) to connect close to 50 institutions, among them all the public and private chartered universities, as well as three of the ten other categories of private universities (Thairu, 2004).

Program for Enhancement of Research Information

The Program for Enhancement of Research Information (PERI) is managed by the International Network for the Availability of Scientific Publications (INASP) and is designed to support capacity building in the research sector in developing and transitional countries by strengthening the production, access and dissemination of information and knowledge (INASP, 2005). INASP is itself a co-operative network of partners whose aim is to enhance world-wide access to information and knowledge. PERl's objectives are to:

- Facilitate the acquisition of international and local information and knowledge

- Improve access to local research through the improved preparation, production and management of local journals

- Provide awareness or training in the use, evaluation and management of electronic information and communication technologies (ICTs)

- Support problem-solving of regional and local information access and dissemination challenges.

PERI endeavours to achieve these objectives through five interlinked and complementary components, each with its own goal and objectives. The components are delivering information; strengthening national research publications; supporting country collaboration and networking; enhancing ICT skills, and research and development. Whereas all these components can be seen to promote access to information resources, the first three components are of particular significance to information resource sharing in institutions of higher learning in Kenya.

All the chartered universities are partners in this INASP-managed co-operative network.

\section{Electronic Supply of Academic Publications}

The Electronic Supply of Academic Publications (eSAP) project is a joint effort of the International Association of University Presidents (IAUP) in cooperation with the International Federation of Catholic Universities (IFCU). Its aim is to set up a sustainable electronic document delivery system for scholarly publications between universities in the North and the South as well as between the universities in the South themselves, by means of the Internet, and thus assist in the supply of academic publications to as well as from the developing world (IFCU, 2005).

The project dates back to 1997 when the idea of a possible co-operation project between IAUP and IFCU in the field of academic information supply by means of Internet, was mooted at the mid-term conference of the International Association of Universities. The idea crystallised into a viable project through discussions at subsequent meetings, culminating into a Memorandum of Understanding between the IAUP and participating East African universities, which was signed in February 2001.

SA Jnl Libs \& Info Sci 2007, 73(I) 
The project is founded on the major belief that access to the international academic resources on the Internet has two core aspects: availability of resources, and knowledge and skills to use the online resources optimally. eSAP believes that the first aspect is adequately addressed by programmes such as INASP and is thus focused more on the second aspect, especially in providing training for academicians. According to Simons (200I) eSAP relates success by partner universities on several theoretical points of departure, including the following:

- Co-operation between universities will increasingly rely on clusters and networks in which one of the key success factors will be sharing of resources;

- In order for universities in developing regions to become more of producers rather than just 'receivers' of academic information, they have to cooperate in acquiring, managing, publishing and distributing information, and

- Electronic communication, particularly the Internet, will rapidly become the main means for transfer and exchange of academic information.

These assumptions have in turn set the agenda for each member university to undertake to fulfil a number of responsibilities, among them the following:

- Manage and make available its proportional share of the academic journals jointly possessed by the cluster;

- Electronic document delivery of articles from these journals to other members;

- Electronically publish the output from its own academic staff members (articles, papers) on the Internet server of the project, and

- Create and maintain the databases needed for the information awareness services (including bibliographic catalogue databases, experts database).

In Kenya, only three universities so far are party to this project: the Catholic University of East Africa, Kenyatta University, and the University of Nairobi.

Database of African Theses and Dissertations

For a long time, the vast bulk of research conducted in Africa has remained as grey literature and has thus remained effectively lost (Sturges and Neill, 1998). There has been a great need, therefore, for developing a mechanism whereby the collection, management and electronic dissemination of African theses and dissertations could be enhanced. These issues were discussed at a meeting organized by the Project for Information Access and Connectivity (PIAC) held in Nairobi, Kenya, in January 1998. The meeting recommended a feasibility study (undertaken between 1998-1999) for a pilot project (carried out between 2000 - 2003) to index, abstract, and distribute theses and dissertations completed in African universities.

This gave rise to the Database of African Theses and Dissertations (DATAD) initiative, an affiliation of the Association of African Universities (AAU). DATAD seeks to collaborate with African institutions to make research output from Africa accessible to researchers and scholars in Africa and other parts of the world. The following are among the programme's long-term objectives (AAU, 200I) which have a strong component of information resources sharing:

- Working with participating institutions to build a regional database of theses and dissertations;

- Creating capacity in African universities for the collection, management and dissemination of theses and dissertations electronically;

- Providing visibility and improving accessibility to the work of African scholars both within and outside of the continent, and

- Promoting cooperation among member universities and networking of institutions.

DATAD advocates a combination of both centralized and decentralized architecture at management and technical levels, which was found most acceptable by institutions and technically feasible given the relatively poor and unreliable ICT infrastructure in most parts of Africa (Materu-Behitsa, 2004).. The centralised activities and processes are concerned with standards, quality control, and coordination, while the decentralised ones are related to data entry, institutional quality control; storage and archiving; provision of full text, and copyright and intellectual property rights management.

Of the II pioneering institutions, only Kenyatta University from Kenya is a partner in DATAD.

Inter-University Council for East Africa

The primary responsibility of the Inter-University Council for East Africa (IUCEA) is to co-ordinate academic research activities for member universities and governments. Its mission is to encourage and develop mutually beneficial collaboration between its member universities, and between them and the governments and other organizations, both public and private. Such collaboration includes resource sharing.

A preliminary review of the core functions of IUCEA and needs assessment among institutions was undertaken, and one of the areas identified for funding was co-publishing, publications and sharing of information through the electronic and print media (IUCEA, 2004). This was partly because of the realisation that there can be no proper co-ordination and implementation of research activities without access to information resources.

SA JnI Libs \& Info Sci 2007, 73(I) 
An important outcome of this process is the East African Network of University Libraries (EANUL) which is designed to help university libraries in East Africa to meet and share experiences, and extend these experiences to their counterparts elsewhere in Africa (IUCEA, 2005). EANUL functions in three chapters for the respective countries. It is expected that when fully operational, EANUL will enable universities in the East Africa region to have an important initiative that will support information resource sharing activities within and among them.

Another important component of information sharing among IUCEA member states is the Africa Learning Network (ALN) created by the United Nations Economic Commission for Africa (UNECA) to facilitate the improvement of ICTs in the learning and teaching process. One of the three pillars of ALN is VarsityNet, which establishes connectivity at universities and related institutions of higher learning and research, and stimulates the development of content production and information sharing within this environment (Ayoo, 2005). In line with information sharing concerns, one of the key aims of VarsityNet is creating the necessary conditions for generating knowledge, which is produced on Africaspecific conditions in the information society for teaching and learning purposes. Currently, all chartered universities in Kenya are members of IUCEA (IUCEA, 2005).

Kenya Libraries and Information Services Consortium

The Kenya Libraries and Information Services Consortium (KLISC) had its humble beginning at a regional meeting of the Inter-University Council of East Africa Libraries in 1998. This led to the idea of establishing an academic and research libraries consortia, which was mooted at a Kenya University Librarians Committee (KULC) meeting held in 2003 in Nairobi.

After discussions in subsequent meetings, the consortium was finally inaugurated at a KULC seminar held in June 2004 and a constitution of the consortium unveiled. The consortium's secretariat is located in the Jomo Kenyatta Memorial Library at the University of Nairobi. Though initially it was intended for academic and research libraries, its membership has widened to include public libraries, archives, and museums. The objectives of KLISC which have a bearing on information resource sharing are to:

- Develop and improve cooperation and understanding among member libraries;

- Provide a forum for sharing information and experiences, and

- Develop cooperative acquisition schemes among members.

In attempting to achieve these objectives, the consortium envisages to move libraries from hardcopy to electronic environment, strengthen access to information through use of ICTs, as well as sensitise and educate librarians, users and managers on modern technological methods of accessing information (Were, 2004). Other activities will include:

- Carrying out research studies, projects and programs leading to knowledge of available resources and services;

- Supporting the implementation of systems and techniques that will facilitate increased cooperation among member libraries, and

- Establishing networks for the development of content, creation of digital libraries and delivery of documents to library users.

This initiative is still in its formative stages, although progress is slowly being made with regard to popularising it to the respective member institutions' authorities. It is, nevertheless, expected that being the only indigenous e-initiative so far launched and with commitment from all members, it will attract goodwill from all those who are expected to support it.

\section{Major achievements}

The overarching objective of all these initiatives is no doubt the enhancement of access to nationally and internationally available electronic information resources by participating institutions. Each of these initiatives have certain unique features that are significant to our discussion and which point to some of the successes that have been realized with regard to achieving the core objective. In general, however, we have chosen to discuss the successes achieved so far from the point of view of the following four main areas:

- Assisting libraries to automate as a prerequisite for online information sharing;

- Facilitating the provision of, and access to the collective bibliographic and other electronic information resources held by partner institutions;

- Supporting collaboration and networking among participating institutions; and

- Developing ICTs skills for personnel in member institutions to enable them participate fully in the information technology environment.

These aspects are discussed further in the sections that follow.

Assisting libraries to automate

Automating libraries is one of the prerequisites for online information sharing. The long tradition of using manual systems in many of the libraries in Kenyan universities has necessitated the need for, first and foremost, sensitizing these libraries

SA Jnl Libs \& Info Sci 2007, 73(I) 
on the need to automate so as to enjoy the benefits of networking. Consequently, almost all the existing networks have been involved in this endeavour to some extent or other.

For example, AVL-K has been able to stir up the need among libraries (through meetings and seminars) to focus on a better future in information service through automation (Wanyoike, 2004). In particular, issues such as those concerning basic hardware requirements, selection of library software, configuration of LANs and retrospective conversion of collections, among others, have received a lot consideration. Indeed, as already pointed out, one of AVL-K's secondary objectives which it has been pursuing vigorously is to assist libraries to automate and put their holdings in an MARC format to aid in establishing a web-based union catalogue. Similarly, KENET is also having a big impact on the application of ICTs in Kenya's academic libraries, particularly recognising their importance as depositories of approximately $70 \%$ of all the library resources in the country (Wanyoike, 2004).

Automation has enabled these libraries to take full advantage of the projects' benefits with the result being enhanced value of services delivered as the libraries graduate to online status (Kinyanjui, 2000).

It is obvious to all the libraries in universities in Kenya, be they actual or potential participants in existing electronic networks that collectively such initiatives hold the greatest promise for the future with regard to sharing of information resources. Consequently, provision of the necessary infrastructure, such as automation and Internet connectivity, is not a mater of choice; it is crucial. It is therefore arguable that on this score, these initiatives have played a big role in laying the groundwork for automation of a good number of the libraries and information centres in universities in Kenya.

Facilitating access to electronic information resources

Facilitating access to electronic information resources is a core business of all the existing initiatives. In particular, AVU has been very visible through its digital library programme, launched in 1998 and which was designed to make scientific information available to African students and faculty in participating institutions (Wolff, 2002). Furthermore, AVU has also developed a web-based portal for the African educational community to share African research results (Wolff, 2002). This has been made possible through the use of asynchronous Internet connectivity (Jensen, 1998).

KENET is also unique in that it is both a network and an ISP, and is thus able to provide Internet gateway services for member institutions to access both local and international databases. It has also provided a platform and infrastructure for electronic teaching and learning as well as resource sharing, through hosting educational databases and strategic institutions' web sites. KENET has, therefore, managed to harness knowledge generated in the country for the common good of the cluster and ensured that national information resources are effectively and efficiently used for sustainable development. In order to enhance its value as a premier educational network, KENET is building a portal that will link to the web sites of the individual educational (partner) institutions.

Similarly, the eSAP project facilitates access to academic resources on the Internet (Mayega, 2005). More importantly, it creates the possibility for academicians in developing countries to electronically publish their articles and reports on the Internet thus making their academic works known and available to the world. This means that universities in Kenya are able to order electronic versions of academic publications from their cluster partners (Simons, 200I).

PERI, on the other hand, supports online publishing of national and regional journals, and a vital outcome of this process is the African Journals OnLine (AJOL), which provides access to African published research and increases worldwide knowledge of indigenous scholarship. AJOL provides access to abstracts, sophisticated searching within AJOL titles, document delivery, and email alerts of newly published issues. Consequently, with many researchers now publishing in electronic format in journals that continue to be added to the AJOL list, electronic resource sharing has been facilitated on a very big scale. Similarly, the 'strengthening national research publications' component is geared towards increased dissemination of national and regional research information.

PERI has also developed useful directories and networks through which information activities are 'mapped' and users with queries are either provided with information or are connected to institutions and individuals with relevant expertise. An important resource base is the INASP Directory (see http://www.inasp/info/pubs/directory/) with over 300 detailed profiles of organisations and activities supporting any aspect of production, access to, and dissemination of, information and knowledge.

DATAD's major achievement is the creation of DATAD OnLine (http://www.aau.org/datad/database), the abstracts database with founding records from the II pioneering institutions, which was launched in 2003 (AAU, 2004). By 2005, the database had over 16,000 records and growing. There is evidence that the DATAD initiative has continued to gain acceptance and momentum within institutions as evidenced by the large number of registered users of the database (Materu-Behitsa, 2005). Partner institutions are able to exchange abstracts of theses electronically through DATAD OnLine as well as through DATAD on CD-ROM. This service will be enhanced as more universities begin to contribute toward building the DATAD database. 
Ubogu (2003) also observes that even before the main database was launched, institutions were reporting various roles it was already playing, including as a:

- Research results dissemination tool to give summaries of the findings;

- Networking tool to give the names of authors, supervisors, and their contact information;

- Quality control tool to bring to light the quality of research undertaken in African Universities, and

- Indicator of the research gaps and reduce duplication

These constitute important aspects of information resources sharing. The DATAD initiative has also been involved in laying the groundwork for initiating electronic theses and dissertations (ETDs) projects. The pioneering institutions in particular are now better placed to embark on more extensive ETD projects as well as in information resources sharing initiatives through improved management and provision of access to their collections of theses and dissertations, courtesy of DATAD (Ubogu, 2003). It is also encouraging that DATAD has been focussing more on expansion, sustainability, access, preservation, and copyright and intellectual management in the future. These are intended to ensure long-term availability of the DATAD resources to the contributing as well as the larger research community.

\section{Supporting collaboration and networking}

The information profession is frequently described as changing from materials-oriented to client-oriented, hence the need for strong inter-institutional relationships aimed at addressing the diverse needs of users. Electronic information networks in Kenya have largely been responsible for the achievement of such inter-institutional relationships through library networking and collaboration.

A case in point is the AVU whose business strategy being implemented since 2002 focuses on the project being a facilitator for networking among partner institutions rather than aspiring to be a degree-granting institution (Wolff, 2002). In this respect, use of asynchronous Internet connectivity is significant because this is the technology most suited to virtual distance learning. Furthermore, with the lowering of the costs of connectivity - significantly wide-band satellite-based Internet connections -institutions of higher learning in Kenya will be more likely able to provide enhanced infrastructure to support information resources sharing among AVU's network of partner institutions.

AVL-K has also provided facilitation in this area through support for other initiatives. For example, it actively participated in the planning of the Kenya Education Network (KENET) project by preparing the concept paper, and contributed in the designed of KENET's project document (Kinyanjui, 2000). Such input has made KENET to be one of the most successful of all the existing information resource sharing initiatives. Its objectives have been achieved to a large extent as evidenced by the large number of institutions already connected to the network. Indeed, a poll conducted by the network showed that $83 \%$ of all respondents who use the network's services felt that KENET has provided the information service of choice for many of the members of the academic community seeking appropriate information for their academic and research undertakings (KENET, 1999).

PERI has also been very instrumental in implementation of enhanced mechanisms for information resource sharing in Kenya. Through the 'supporting country collaboration and networking' component, PERI has supported a number of national networking and consortia building activities including the following (INASP, 2005):

- Discussion and collaboration fora. These are intended to provide individual libraries and information centres opportunities to discuss issues unique to them with regard to sharing and building capacities to manage information resources. Such fora include meetings of country coordinators as well as ad hoc meetings, workshops and other events to bring together participants in-country, and

- Negotiation and licensing skills for library networks, where librarians learn skills in managing electronic networks for purchasing, managing and disseminating the resources available.

There has also been significant achievement with regard to co-operative subscription to electronic journals. INASP negotiates with major international publishers on affordable and sustainable access licences. Universities, among other not-for-profit educational and research organizations pay an annual nominal subscription fee in return for low-price access to high-value content. Through this arrangement, made possible by PERl's 'delivering information' component, Kenyan universities have access to thousands of full text journals with virtually no cost at point of use.

PERI looks certain to continue to be an important player in the efforts to develop sustainable networks for information resource sharing among Kenyan universities, in much the same way it has impacted strongly on provision and access to affordable scientific and research information by these institutions.

DATAD's contribution in this regard has been three-fold: development of DATAD LISTSERV, facilitation of meetings and workshops, and developing capacity to provide the DATAD database on CD-ROM. The first two have enabled participants in the DATAD initiative to discuss issues of common concern and find common ground for addressing problems that they individually and collectively face in their attempts to build a sustainable network. Development of 
DATAD on CD-ROM is an important undertaking for those institutions without full Internet connectivity because they are able to provide scholars with access to research information through this format.

Assistance in ICTs skills development

Some of the networking projects have taken cognizance of the fact that just helping libraries to automate is not enough; this must be backed up with provision of appropriate skills to manage the networks as well as to ensure optimization of resources accessed. Consequently, developing ICTs skills for personnel in member institutions to enable them participate fully in the information technology environment has become a major undertaking alongside other implementation issues. This is given impetus by the fact that there is always shortage of ICTs skilled personnel in our libraries and information centres.

An important trend in the provision of ICTs skills is that many of the networks are targeting skills development in specific areas. For example, KENET aims to develop skills to enable document processing, specifically paper-to-electronic format conversion. Similarly, PERl's focus is on providing awareness or training in the use, evaluation and management of ICTs. Indeed, one of the core ways through which PERI provides support to librarian communities is the 'enhancing ICT skills' component.

eSAP also has been actively involved in providing training for academicians to be able to utilise the Internet resources as a prerequisite for successful access and use of available e-resources. Even DATAD has put some effort in this regard through creating capacity in universities for the collection, management and dissemination of theses and dissertations electronically.

However, AVL-K appears to be the only one that has implemented a structured ICTs training for its member institutions. The project has developed a curriculum for post-graduate diploma in information management in conjunction with the Kenya Institute of Management with the purpose of training young African graduates to spearhead information revolution in Africa. According to Kinyanjui (2000), the training programme offered by distance learning through the African Information and Communication Technology Institute (AICTI), an initiative of the AVL-I, is designed to produce information managers who will constitute the nucleus team to work towards a new approach to information management in Africa.

\section{Shortcomings}

Although some gains have been realised with regard to information sharing through networking, the road has not been easy. Indeed, a study by Onyancha and Ocholla (2006) indicates that there are very poor inter-university linkages in Kenya with majority having only one web inter-connection. This presents a significant drawback in the successful implementation of resource sharing and could be attributed to a number of factors.

First, many of the potential participating institutions are still struggling to automate their libraries and this no doubt impacts on the individual institution's ability to fulfil their tasks and responsibilities. As Wanyoike (2004) observes, the magnitude of the task to mobilise libraries to automate and network almost from scratch is tremendous in view of the various administrative and financial difficulties associated with institutions in the country.

Libraries are also required to first build and maintain their electronic databases before they can begin to think of sharing the information resources jointly owned by the cluster. Yet, many of the projects are initiated with the assumption that individual institutions have the capacity to create and maintain databases necessary for networking as well as the means to implement electronic communication facilities.

The lack of capacity is mainly as a result of inadequate resource allocation for information services. This is exemplified by the fact that public universities in Kenya (as indeed in many sub-Saharan African countries) depend on national governments to fund $90 \%$ of their recurrent and capital budgets (Raseroka, 1998). Consequently, when economic fortunes take a downturn, funding for these institutions go down considerably, occasioning serious decline in service delivery. This is made more difficult by the fact that member institutions are obligated to provide resources for sustenance of any network project.

For example, each university participating in eSAP must implement a financial write-off system for the project equipment where the project finances the initial purchase of the essential technical equipment, but individual universities undertake to help make the project sustainable by, among other things, replacement or renewal of the equipment. These resources are sometimes difficult to secure from university administrators.

The cost of connectivity is another major problem which is left to the participating institutions to handle for themselves. Except for a few initiatives such as KENET which has an arrangement with Telkom Kenya to offer lower tariffs (up to $50 \%$ of the commercial rates) for subscribing institutions, other networks do not have such initiatives. Consequently, a good number of institutions which qualify for membership have not been connected due to the high cost of bandwidth and infrastructure. Moreover, even for those institutions that are already connected, there has been 
discontent with insufficient bandwidth allocated to them which causes slow system response occasioned by congestion especially during peak hours.

There has also been a high turnover of expert staff both at the networks' as well as at the institutions themselves which has slowed implementation of some activities envisaged by some of the networks. For member institutions, inadequately trained manpower to properly manage the networks' services has been a major stumbling block to successful implementation and sustainability. A case in point is KENET which has yet to implement one of its key services relating to repackaging of local content in electronic format and sharing across the Internet, which would greatly assist in information resources sharing.

For some of the networks, problems arise due to limitations placed in accessing the databases. For example, in order to have full access to the DATAD database, users need to subscribe or connect from a subscribing institution. This presents a hurdle for resource sharing because a researcher must be affiliated to an institution that is registered in order to enjoy the privilege and low cost of collective membership.

Another factor that hinders successful implementation of many of the initiatives is lack of clarity on how to respond to requests for full text. Materu-Behitsa (2004) opines that in the case of DATAD this is possibly due to absence of clear policies on copyright and access provisions. This could as well be true of many of the other initiatives. There is also lack of clear strategy for implementation of sound preservation policy for electronic copies of works from participating institutions, which is essential to ensure long-term availability. Even though this has been noted especially for DATAD (Materu-Behitsa, 2004a) this is a problem that affects all local networks and this represent an obstacle to the success of the initiatives.

Significantly also is the selfish attitude among universities in Kenya as each one tries to gain a more competitive advantage with regard to increasing their enrolment figures. For example, Onyancha and Ocholla (2006) found that one of the reasons for the poor collaboration among Kenya universities (attributed to one computer science lecturer) was that the universities are competitors and cannot therefore advertise each other's services, products, or even curriculum on their websites.

Nevertheless, it would appear that many of shortcomings are identical for all the existing electronic information sharing initiatives essentially because they operate in similar information environments. There are both structural and conceptual problems. Were's (2004) concerns with regard to the challenges that KLISC has to contend with if the consortium is to succeed embodies the challenges that all other networks grapple with. These include: sustainability; change of priorities (say from building collections to enhanced access); provision of reliable connectivity; insufficient and costly bandwidth; lack of technical know-how, and low level of technological infrastructure.

\section{Conclusion}

This paper has addressed itself to some of the major information resources sharing initiatives in universities in Kenya. The increase in the value and demand of information continues to exert pressure on libraries to offer more effective service to their users. There is no doubt that the advent of ICTs has brought about a complete revolution to the library's traditional roles of retrieval and dissemination of information. In view of the liberalisation of information provision through ICTs, information services are beginning to shift focus from accumulation and ownership of information resources, to providing access, hence the emergence of many online initiatives.

Although on-line information sharing networks are not a panacea to all the problems facing information providers in these institutions, they are, nevertheless, expected to open new avenues, enabling users to have access to vast information resources available within international databases. Such initiatives have had their share of successes and failures. The absence of clear policies and institutional commitment in providing the necessary infrastructure has slowed the process of establishing a national information network envisaged by many of these initiatives. Libraries and information centres in our universities have also had to deal with their internal problems, especially lack of funding.

However, there are very good indicators that on-line information has started to play a significant role in addressing the issue of information scarcity in the universities, as evidenced by the achievements of such projects like PERI and KENET. In order for such initiatives not to appear to be 'initiatives of the future', Kenyan universities must make serious commitment in investing in ICTs infrastructure and provision of sufficient resources to enable more effective and efficient information resources sharing. Moreover, focus should be more on scaling up activities that have been successful rather than those that may retard progress.

\section{References}

Association of African Universities (200I). Database of African Theses and Dissertations - DATAD. [Online] available: http:// www.aau.org/datad. (Accessed August 15, 2005).

SA Jnl Libs \& Info Sci 2007, 73(I) 
African Virtual University (AVU, 2004). AVU digital library. [Online] available: http://www.avu.org/section/library.cfm? (Accessed February 24, 2006).

The African Virtual University (AVU, 2005). About AVU. [Online] available: http://www.avu.org/ (Accessed November 4, 2005).

Ayoo, Philip O (2005). The IUCEA brings together East African universities to undertake joint research in open source software for egovernment.. [Online] available: http://www.iucea.org/show_news_details.php?item_id $=10$ (Accessed July 10, 2006)

Board of Trusteess of the Leland Stanford Junior University (2004). African Virtual Library initiative. [Online] available: http:// www.sul.stanford.edu/depts/ssrg/africa/libaf.html (Accessed November 20, 2005)

International Network for the Availability of Scientific Publications (INASP, 2005). Programme for the Enhancement of Research Information (PERI). [Online] available: http://www.inasp.info/peri/intro.shtml (Accessed December I2, 2005).

International Federation of Catholic Universities (IFCU, 2005). Electronic supply of academic publications to and from universities in developing regions (ESAP). [Online] available: $h t t p: / / w w w . f i u c . o r g / i a u p / e s a p /$ (Accessed December 14, 2005).

Internet Foundation - Kenya (2002). African Virtual Library Initiative. [Online] available: http://www.inasp.info/peri/intro.shtml (Accessed November 20, 2005).

Inter-University Council of East Africa (IUCEA, 2004). About IUCEA. [Online] available: http://www.iucea.org (Accessed November 2, 2005).

IUCEA (2005) Member Institutions. http://www.iucea.org/General_Public/member_universities.php (Accessed July 10, 2005).

Jensen, Mike. (1998). African Internet connectivity: summary of international ICT development projects in Africa. [Online] available: http://www3.sn.apc.org/africa (Accessed November 8, 2005).

Kamau, N. (2002). Breaking Information Access Barriers: the African Virtual Library Initiative (AVL-I). [Online] available: http:// www.hipnet.org/ppt/200I/kamau/sld0/4.htm (Accessed December I5, 2005)

Kenya. Commission for Higher Education (CHE, 2006). Accredited Universities. [Online] available: http://che.or.ke/ accreditation.html (Accessed June 20, 2006).

Kenya Education Network (KENET, 1999). About KENET. [Online] available: http://www.kenet.or.ke/ (Accessed November 4, 2005).

Kinyanjui, William (2000). The African Virtual Library Initiative (AVL-I): the strategy for information management for sub-Saharan

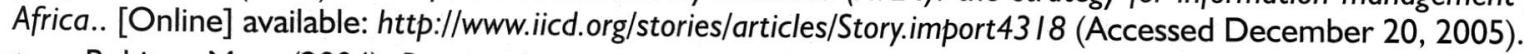

Materu-Behitsa, Mary (2004). Resources to support research in Africa: the Database of African Theses and Dissertations (DATAD). [Online] available: http://www.sist-sciencesdev.net/fichiers/Seminaires/Presentations_Accra/DATAD.ppt (Accessed December 16, 2005).

Materu-Behitsa, Mary (2005). Database of African Theses and Dissertations (DATAD): copyright and IPR management challenges.

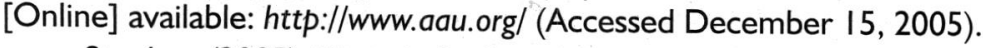

Mayega, Stephen (2005). The supply of academic publications to and from universities in the developing regions by means of Internet. [Online] available: $h t t p: / / w w w . a e p i c . i t / c o n f / v i e w p a p e r . p h p ? i d=57 \& p r i n t=1 \& c f=3$ (Accessed December 14, 2005).

Ocholla, Dennis (1995). Professional development, manpower education and training in information sciences in Kenya. [Online] available: $h t t p: / / c e r e s$.emeraldinsight.com/vl=34/80/4=48nw $=I / f m=h t m l$ (Accessed August I6, 2005).

Odini, Cephas (1991). "Problems and prospects of resource sharing in developing countries." African Journal of Library, Archives \& Information Science, Vol. I, No.2, pp. 93-98.

Onyancha, O.B., Ocholla, D.N. (2006). African institutions of higher learning: ripe for cybermetric studies? Performance of South African and Kenyan universities on the World Wide Web. Paper presented at the $8^{\text {th }}$ Annual Conference on World Wide Applications held on $6^{\text {th }}-8^{\text {th }}$ September 2006, at the University of the Free State, Bloemfontein, South Africa.

Raseroka, H.K. (1998). "Skills for information professionals in academic libraries in sub-Saharan Africa." In Information for sustainable development in the 2 Ist century: proceedings of the $13^{\text {th }}$ Standing Conference of Eastern, Central and Southern Africa Librarians, $27^{\text {th }}-31^{\text {st }}$ July. Nairobi: Kenya Library Association.

Simons, Eduard (2001). S.A.P.: the supply of academic publications to and from universities in developing countries. [Online]

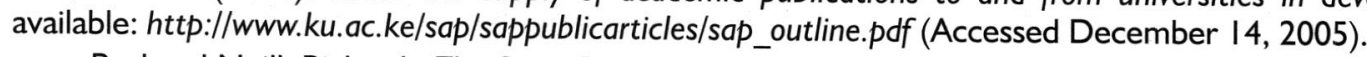

Sturges, Paul and Neill, Richard: The Quiet Struggle: Information and Libraries for the people of Africa. $2^{\text {nd }}$ ed. Masell: London and Washington, 1998, p. 168.

Thairu, Henry M. (2004). Kenya Education Network (KENET): interconnecting academic and research institutions for the sharing of

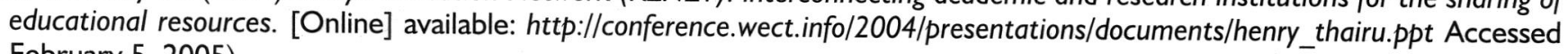
February 5, 2005).

Ubogu, Felix N. (2003). From DATAD to ETDs: the way forward. [Online available]: http://edoc.hu-berlin.de/conferences/etd2003/ ubogu-felix/PDF/index.pdf (Accessed December 16, 2005).

Wanyoike, John (2004). The camel comes of age: academic and public libraries' partnership in sharing information through information technology in Kenya - the role of African Virtual Library project. [Online] available: http://www.ala.org/ala/iro/ iroactivitiescamecomesage.htm (Accessed August 20, 2005).

Were, J. (2004). Getting affordable access to scientific information for teaching and research: experience of Kenyan universities. [Online] available: $h t t p: / / w w w . i n a s p . i n f o / s y m p o s i u m / 2004 / S y m p-2-2-W e r e . p p t$ (Accessed December 16, 2005)

Wolff, Laurence (2002). The African Virtual University: the challenge of higher education development in sub-Saharan Africa. TechKnowLogia, Issue Number 16, April-June. [Online] available: http://www.techknowlogia.org/ (Accessed November 2, 2005).

World Bank Group (1998). The African Virtual University. [Online] available: http://www.worldbank.org/wdr/wdr98/africa/ bpafr9.htm (Accessed November 12, 2005) 